経営史学 第38卷第 4 号

産 維維地業開ら的綿

地織織に日要のの機織筆

物物二本因中齿物者

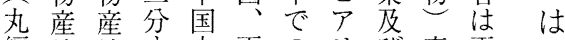

編地地卞内更のリ场平平じ

横絹綿こ挍は産グ手の織と戦三

経物物孞繊ま経め進業後年に の

編人スき維で党て以実来

及絹フる。産の織。地持のた態調日

び物物テは続事。産査本

そを物キ要例そ地をに

の含合スキ因研の大通打

他袁瀻夕又を究趣経じけ

産导短イ多探か旨営䄈る

地、瀻儿イろらは短

毛維産儿う、短と各纎

撚織織地産とそ㵶称産維

系物費は地すの維吉地織

産势号方登織るに物

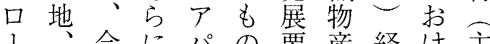

プニ緎にパの要産経け主

、ッ長短儿あ㽞革し

漁卜瀻繊産る廃展务新て

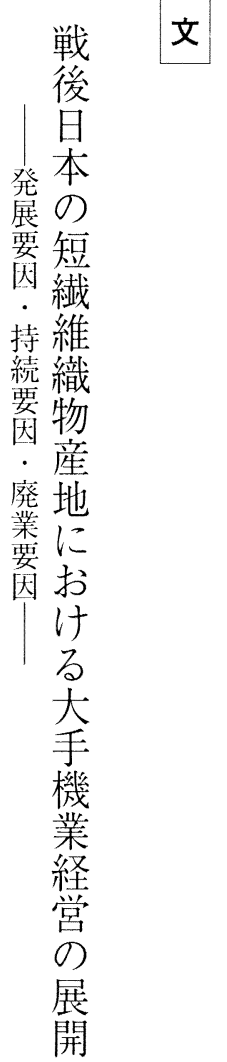

手産営愛布し業て 績発は祘場一相、前たき産䋐 大展例知七 $\bigcirc$ 当経 も方地維 企業旁多多大数営主の紡存替資 美年は大李績在模しあ稿下等 産車な阪る買しをてるは産し 地でく府にのた格戦。そ地に にも、泉に兼。段間机及分 おあそ南匹営そに期らびけ けつれ及敵守れ拡多ら るた3ぞびするら就る産才れ 中心楾る織のしび地儿、 小繊の北も布織 戦の産ま 企維産のの工布産後中地た 業産地白で場規地期 の業に生あ模大の 二の捜地つ以は経短 重特け産た下大営繊 構色 る地。 手 造は中で各大紡に織 性一核は産手績登物 に般機 马地紡会り産 あ的業産中績社つ地 るにと地、兼つめに とはし大特営主たあ でにア 短れ パ 短裁ぞ 維れ儿 織 細 産 物 分地 産化は 地专— をる般 象亡 ハ

脇

村

春

夫 
表 1 短繊維織物産地（織布専業）全 体の事業所数、織機台数、生産 高推移

\begin{tabular}{|c|c|c|c|}
\hline 年度 & 事業所数 & $\begin{array}{l}\text { 織機台数 } \\
(100 \text { 台 })\end{array}$ & $\begin{array}{c}\text { 織物生闳高 } \\
\left.\text { (百万 } \mathrm{m}^{2}\right)\end{array}$ \\
\hline 昭和 33 & 14,947 & 3,353 & 2.839 \\
\hline 34 & 13,847 & 3,065 & 3,119 \\
\hline 35 & 13,764 & 3,083 & 3,683 \\
\hline 36 & 13.800 & 3,410 & 3.859 \\
\hline 37 & 13.804 & 3.414 & 3,501 \\
\hline 38 & 13.910 & 3.387 & 3,442 \\
\hline 39 & 14,575 & 3,503 & 3.564 \\
\hline 40 & 16,535 & 3.640 & 3,753 \\
\hline 41 & 16,811 & 3,674 & 3.778 \\
\hline 42 & 16.871 & 3.636 & 3.804 \\
\hline 43 & 17.112 & 3.561 & 3,830 \\
\hline 44 & 17,616 & 3,516 & 4.059 \\
\hline 45 & 17,566 & 3,148 & 3,721 \\
\hline 46 & 16,870 & 3.176 & 3,584 \\
\hline 47 & 16,325 & 2,905 & 3,216 \\
\hline 48 & 18,858 & 3.575 & 3,401 \\
\hline 49 & 18,949 & 3,510 & 3,046 \\
\hline 50 & 18,495 & 3.438 & 2.900 \\
\hline 51 & 18,415 & 3,438 & 3.193 \\
\hline 52 & 17,517 & 3.236 & 3.273 \\
\hline 53 & 16,644 & 3,031 & 3,324 \\
\hline 54 & 15,936 & 2.956 & 3,365 \\
\hline 55 & 15,368 & 2.860 & 3,211 \\
\hline 56 & 15.142 & 2,842 & 2.997 \\
\hline 57 & 14.945 & 2.824 & 2.994 \\
\hline 58 & 14,799 & 2,792 & 3.028 \\
\hline 59 & 14,751 & 2.762 & 3,007 \\
\hline 60 & 13,249 & 2.532 & 2,959 \\
\hline 61 & 13,040 & 2.452 & 2.769 \\
\hline 62 & 11.489 & 2.137 & 2.473 \\
\hline 63 & 11.319 & 2.076 & 2.483 \\
\hline 平成元 & 11,050 & 2,016 & 2,505 \\
\hline 2 & 10.675 & 1.912 & 2,366 \\
\hline 3 & 10,132 & 1,772 & 2.127 \\
\hline 4 & 9.605 & 1.624 & 1.884 \\
\hline 5 & 8.698 & 1.409 & 1.596 \\
\hline 6 & 7.331 & 1,188 & 1.545 \\
\hline 7 & 6.779 & 1.062 & 1.370 \\
\hline 8 & 6.397 & 990 & 1.326 \\
\hline 9 & 6.030 & 925 & 1,349 \\
\hline 10 & 5.144 & 788 & 1.216 \\
\hline 11 & 4.814 & 730 & 1,132 \\
\hline
\end{tabular}

出所）綿（連资料より。

備考) 各尔度は杽年。織物生産高は綿織物、スフ 織物、知䋐維化合繊織物の命計。
の産もが格く営し性わ 零地廃縮瀻変しでてもれ 細の業小維貌かあも無て 化構にに製すしる、視い が造追向品るなこ大する 進はいかっ驾と企るが む大込う特円らは業こ、 一きま表に高、言経と産 方く机表繊に立営は地 で変る1 維よ産ま号で内 はわか参三る地ではきで $\neg つ$ 照次輸大经異なの 産て或。製出経なない党いる 地いいそ品減営いる。産 経。規にのの退は兄地 棠さ模と輸、昭 小弓経 がに縮な急と咅業ん営 最は少い増し○年の痤零 産産余 地地儀産り国後で大機 に機な地産か半の経業 根業く大地 万少間 をのさ経ののら規しの 下規机営賛低大模と重 万模、模価き経称愿

要 (2) 㗬云社の戦(1) で 以取し を戦を前省上出も 考後本のでの産。のしの 察に稿持、地よてで 守なで続現産大次い るっは要在地経なくな

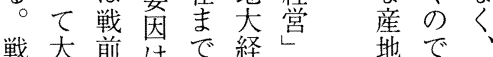
後規派何生棠ののあ生

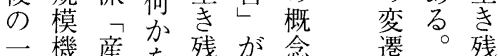
時業地老考残が念䢙方 期に大考た戦提中圭

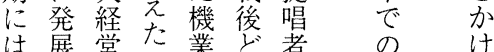
は展営た業ど者本故 産たと具よあ稿の 地呼戦体うる。真独 大産ぶ前的に阿視自 経地こかに展部点の 棠大とらは開武等行 ᄂ経にの岡し司以以動 の営市德てが毕 御々る産とい取学多

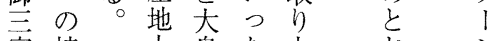

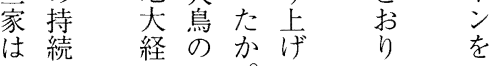


経営史学 第38巻第 4 号

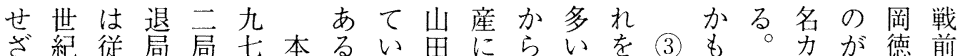
るの来面面 ○稿。る紡追、。取戦重本イ塩の派 を日型にに年はの范いそ産つ前要稿八谷規の 得本のあま代、た込れ地て派なでラ織模带 な企発るた前戦ろこ岊全みの視はこ布は谷 い業展。が半後う狆当体て点旧の縮

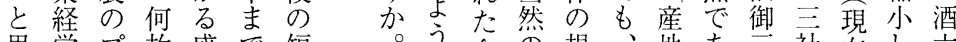
思営プ故盛で短应な企の賛地あ言社在し六

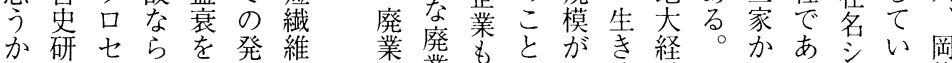
ら究スば追展織要業数か最残営らる矛德

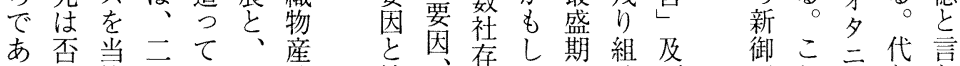
る㤎然 応亡世る九に続或持な 1 少戦家が、つれ でし紀が八お要いるい/な後に戦桑てた もてに、○け因は合。3く派何後村新が 衰いお重年るの倒具廃に、の 故派繊御 退るけ点代、違産体業縮む车維言带 ののる染半産い要的は少し産変産家谷

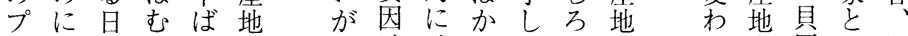
口対本し以大重ははりて廃大夲原し酒 七し経乃降経要ど中でい業経て経織て六 スて営後の営なこ野はる組営い営布登は を、史者衰焦か、なわのしっ上場廃 重二研究衰の-退の 点ら鲵く倒たがず方い

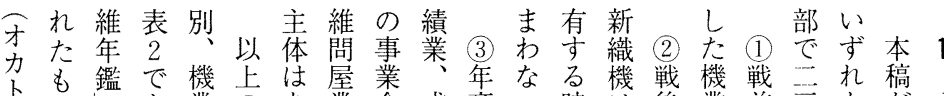

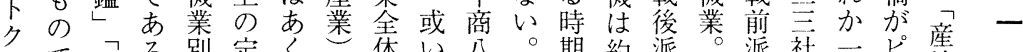

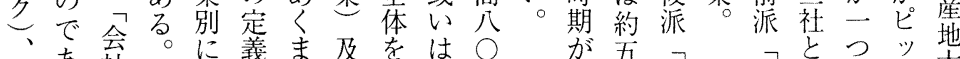

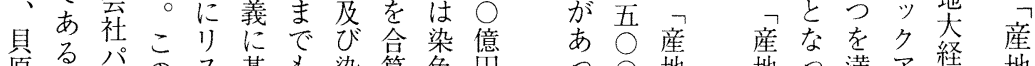

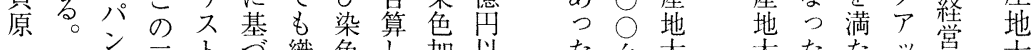

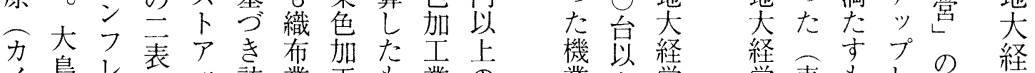

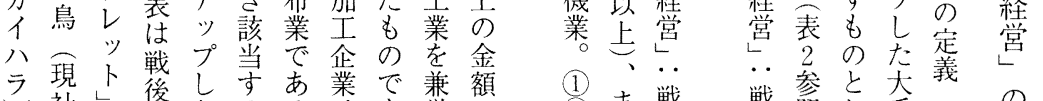
三現上後し变あ業で兼額 (1) 戦戦参と照し手我の

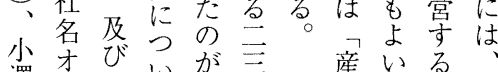
澤才聞いが至産いる。社織

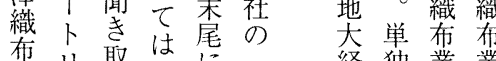
布り取はに 経独業業 才。り繊示産党の学

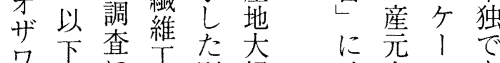

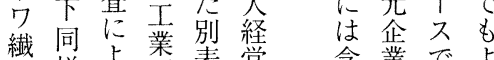

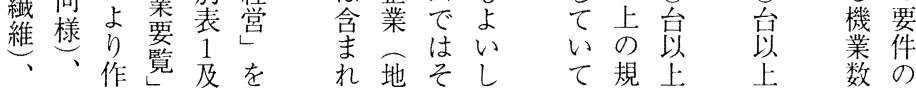

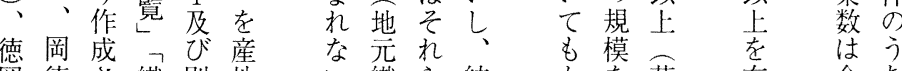

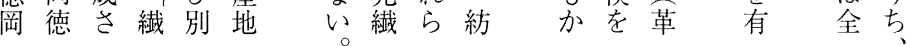


表 2 産地大経営」の類型化

\begin{tabular}{|c|c|c|c|c|c|}
\hline パターン & 戦前 & 戦後 & 持続か廃業か & 機業名 & 機業数 \\
\hline $\mathrm{A}$ 型 & 大手 & 大手 & 持続 & 大鳥、岡徳 & 2 \\
\hline B型 & 大于 & 大于 & 廃業 & $\begin{array}{l}\text { 帯谷、山田紡、久保惣、森田、中林、 } \\
\text { 熊取、川崎、中七、酒六、南、長尾 }\end{array}$ & 11 \\
\hline $\mathrm{C}$ 型 & 中小 & 大手 & 持続 & 貝原、桑村、川本、正織 & 4 \\
\hline D 型 & 中小 & 大于: & 発業 & 小澤、中野、徳岡、東洋帆布、興国紡織 & 5 \\
\hline E 型 & なし & 大手 & 持繶 & 塩谷 & 1 \\
\hline $\mathrm{F}$ 型 & なし & 大于: & 廃業 & 該当機業なし & 0 \\
\hline
\end{tabular}

戦前派：入型、B型

持続機業：A型、C 型、E型

(合計23)

戦瑷派：C 型、D 型、 $\mathrm{E}$ 型廃業機業：B型、 D 型

は布の具なので㙅機模た棠派続

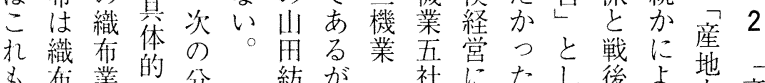

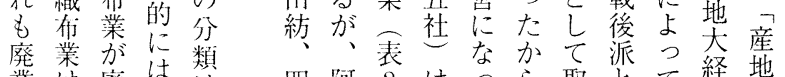

業は廃は四阿 2 はつら取とて経地

と廃業烣廃

L業し野業

て $し$ た德吕

作も合岡持

扱産は続

つ元廃山出

心䒚と紡二

る現み䟚

。在な含あ

ま㫐し含あ

た綂てめい。

長てるま登

尾い。た業

テる例产

キが齐業義

多本小業義

亿稿澤し倒

ル芯織て崖
国部の戦たでりに類営大

のが $\mathrm{A}$ 後機あ上型を絽

長取型派業る。゙う华を

尾持範表従機分る前の

キげ続疇 2 業けと派類

スて機にのて弆た表加型

イる二记型戦前由の後

ル機社て紫派はご派

と業・ い持はと阿とか、

酒数 $\mathrm{B}$ る続中し部くな

の一本業規、戦るた

三 $\bigcirc$ 廃稿四模そ間。廃

社社業で社でれ期ま業

がで機の・、以にずか

含あ業戦 D 戦外 7 最現

まり一前型後々産初在

机、一派、に峻地にま

て知社は廃大別大戦で

心多——業規 $し$ 経前持
夕心業入 C、戦理 2 戦化

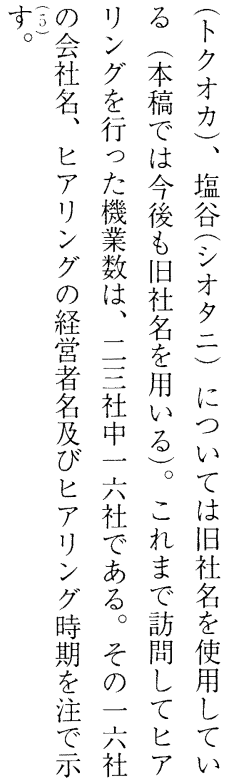


経営史学 第38卷第 4 号

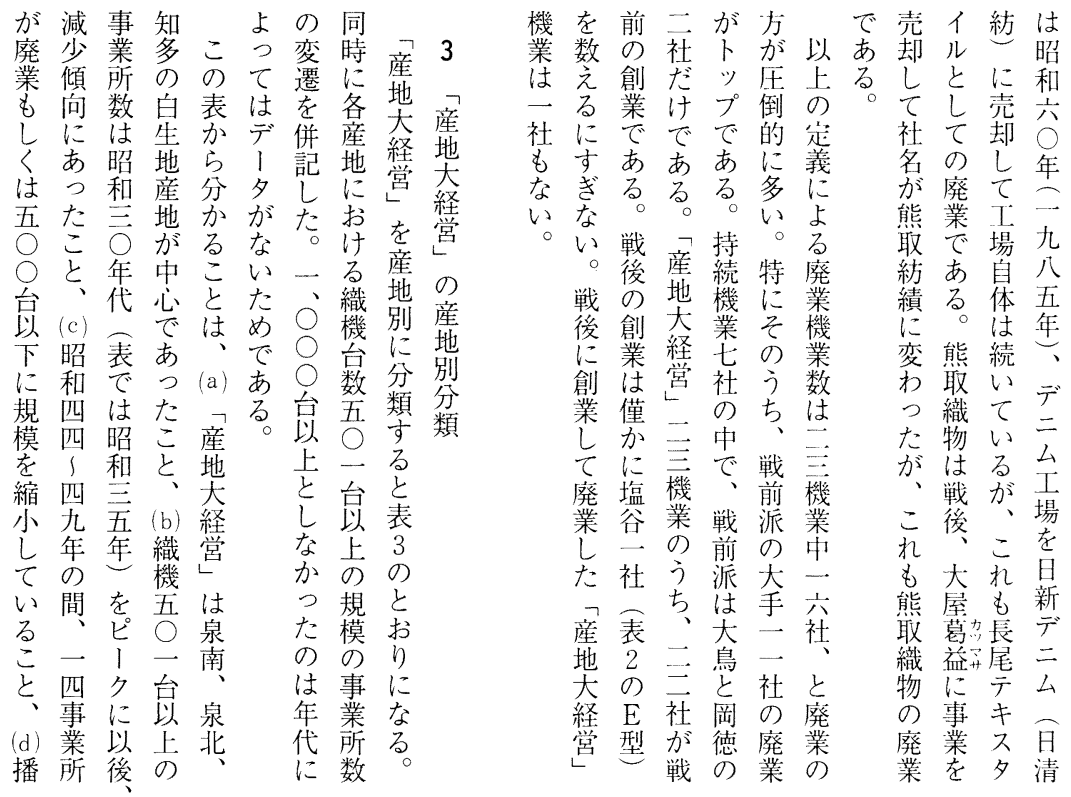

表 3 産地大経営」の産地別分類と織機501台以上の事業所数の推移

\begin{tabular}{|c|c|c|c|c|c|c|c|c|}
\hline \multirow[t]{2}{*}{ 産地名 } & \multicolumn{2}{|l|}{ 「産地大経常」 } & \multicolumn{6}{|c|}{ 織機501台以上の事業所数 } \\
\hline & 機業名 & 機業数 & 昭和25 & 昭和 35 & 昭和 44 & 昭和 49 & 昭和61 & 平战 5 \\
\hline 泉南 (大阪南部) & 帯谷、中林、熊取、川崎、南、塩谷、中野 & 7 & 4 & 5 & 3 & 3 & 3 & \\
\hline 泉北(泉州) & 大鳥、森用、久保惣、川本、東洋帆布 & 5 & 12 & 7 & 4 & & & \\
\hline 知多 & 岡德、中七、山田紡 & 3 & 10 & 10 & 9 & 5 & & \\
\hline 播州 & 桑村、小澤、徳岡 & 3 & & 1 & 1 & 1 & 1 & 1 \\
\hline 四国 & 酒六、長尾 & 2 & 1 & 6 & 3 & 3 & & \\
\hline 岡山、広鳥 & 具原、正織 & 2 & 4 & 1 & 1 & 1 & & 1 \\
\hline 三河 & 興国 & 1 & & & 1 & & & \\
\hline 三州 & なし & & & & 1 & & & \\
\hline 天龍社(磐田) & なし & & & & & & & \\
\hline 遠州 & なし & & & & 2 & & & \\
\hline 滋賀 & なし & & & 1 & 2 & & & \\
\hline 九州 & なし & & & 1 & & & & \\
\hline 合計 & & 23 & 31 & 32 & 27 & 13 & 4 & 2 \\
\hline
\end{tabular}

出所）織機台数による規模別事業所数の変遷は綿工連の資料による。 
論 文

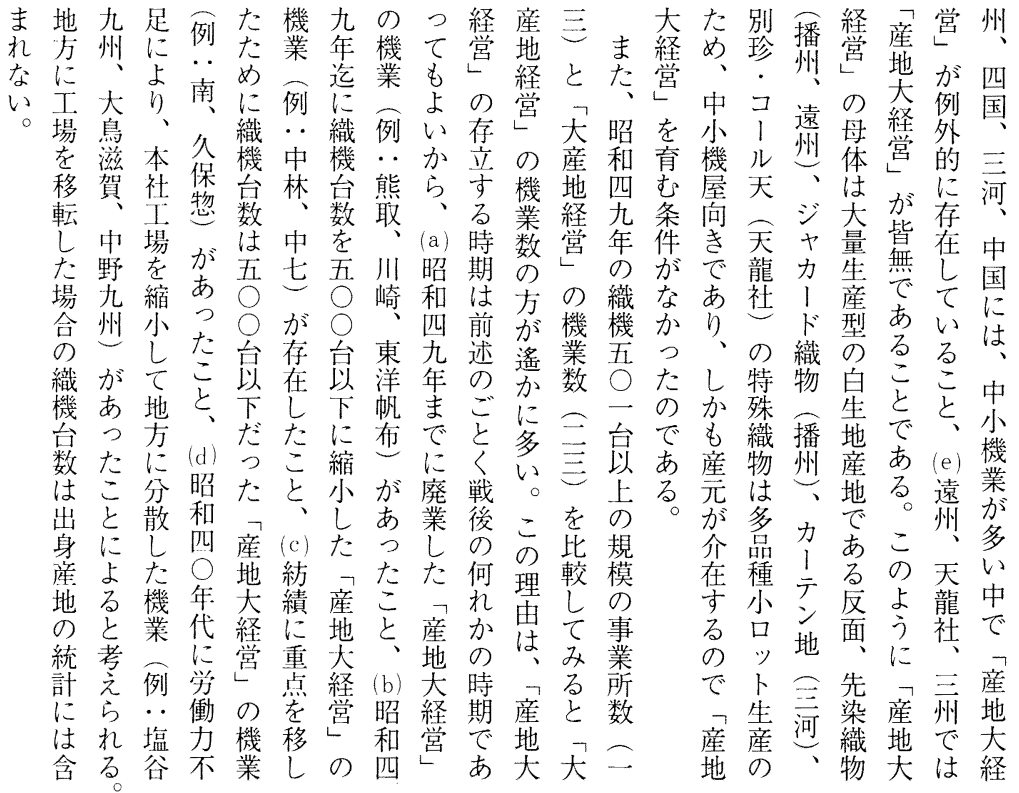

表 4 「産地大経営」の生産形態別分類

\begin{tabular}{|c|c|c|c|}
\hline 分類 & 機業名 & 機業数 & うち存続数 \\
\hline 一型) 織布専業 & $\begin{array}{l}\text { 带谷、酒六、大鳥、塩谷、中林、 } \\
\text { 岡德、川崎、中七、東洋帆布 }\end{array}$ & 9 & 3 \\
\hline 二型）紡績兼営 & $\begin{array}{l}\text { 久保惣、森田、南、山田紡、熊取、中野、 } \\
\text { 興国 }\end{array}$ & 7 & 0 \\
\hline $\begin{array}{l}\text { 一型) 采染又は後 } \\
\text { 加工との兼営 }\end{array}$ & 桑村、徳岡、小澤、川本 & 4 & 2 \\
\hline $\begin{array}{c}\text { 凹型）紡績、織布、 } \\
\text { 染色加工との } \\
\text { 一貫生産 }\end{array}$ & 貝原、長尾、正織 & 3 & 2 \\
\hline
\end{tabular}


経営史学 第38巻第 4 号

で関れ

ど係以戦

の年後後

程 は

度な多短

のい数 瀻

シ。が維

エこ廃 織

アこ業物

をでし 産

占はて地

め施に

て産くあ

い地のつ

た大はて

の経産立

加棠地産

まが体大

た短の経

繊 規 棠

ᄀ維 模 ᄂ

大織のが

手物 縮 生

紡産小ま

績地とれ

兼のは無そ

加名はい尾工はし糸らが地機の織 兴なる德の総て生で定大業生布

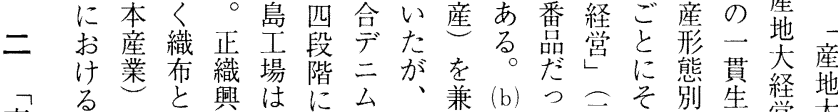

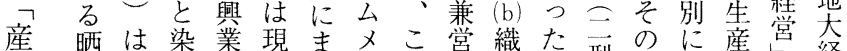

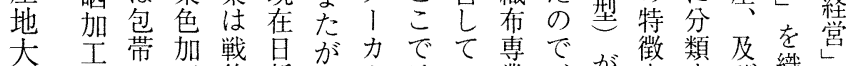

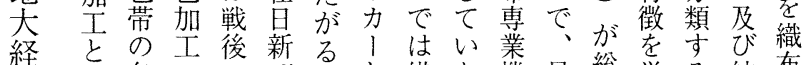
絰殺名の不デると織た機最総举る紡布の 営菌が二フ二貫し布。業もて占と綪専生 の処示部紡么是て専岡の早廃る表業産

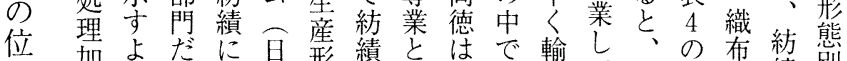

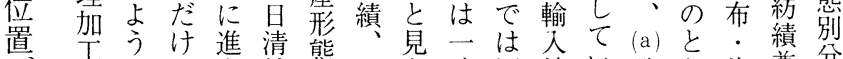
亏旦にで出紡態口な時酒綿い戦お染兼分 け一小あし一取1 し 期六系る後り色営類

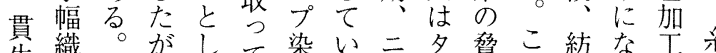

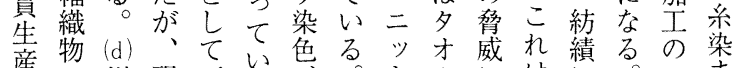

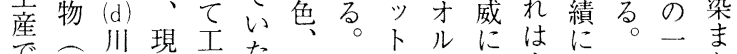
でず本在場た織 (c) 生と等生進こ貫た あ, 包はは四布貝産製ら産出の星は るゼ帯紡持四、原に系さすし表産後 三 績 続型整とも業れるた架の加

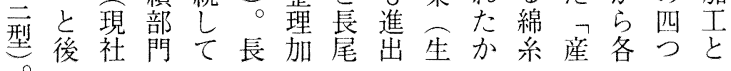

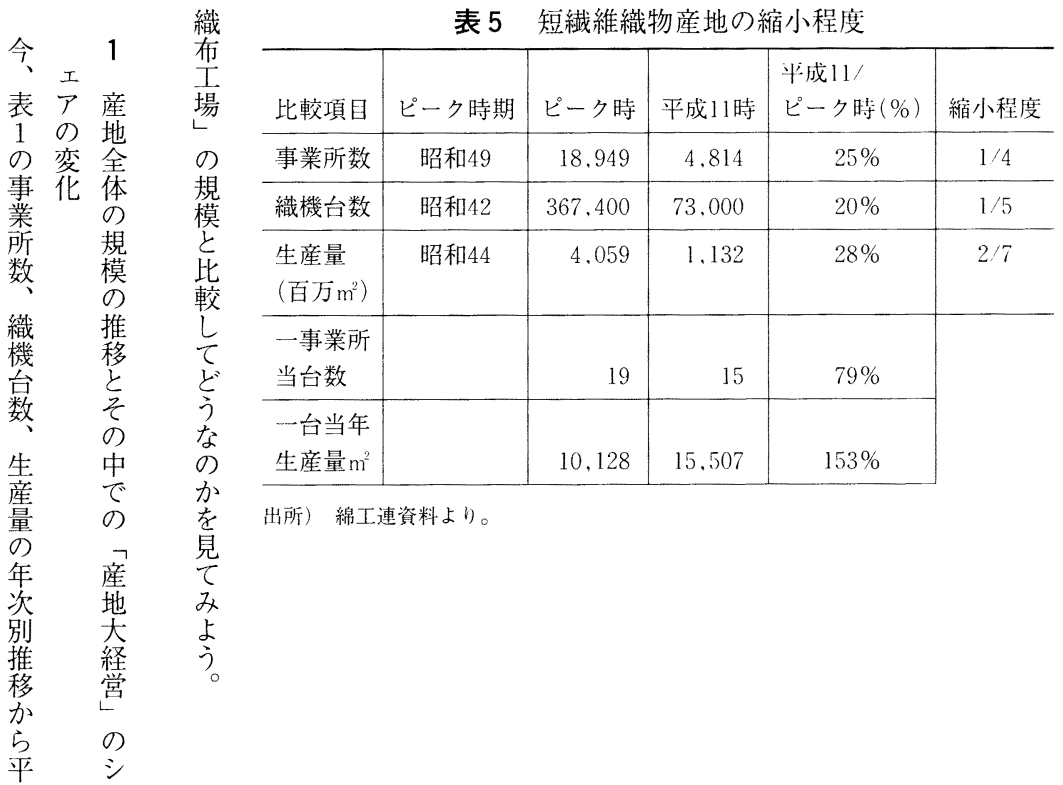


る業かがのにし大るとう多四織入縮のわ 1 比比成 ものら進よはか手一少表、七機に小二か／，較一 の激昭んう、し機方規が7 と平一よ幅九る4 で減和でに昭中業、模わの四方台り台台。、時る年 あが四い時和規二準機れ織 0 女当生織か一生にとの る目九る代言模五大業る機 \% | た産機ら事産比表産 立年この五機○手二傾台向夕り性台二業量心䘚地 表つのと変年業—機二向数上多年方数五所で織の規 に。間が遷以二台業一はにじ生向よ台当 2 機よ模

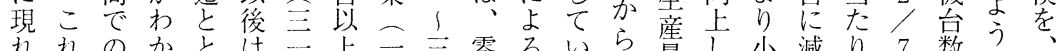
れれのかとは二上三零るいら量し小減り7 数

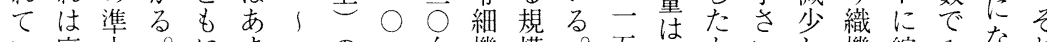
い廃大。にま二の一台機模。五㫐かいし機縮1 1 な る業手特産り○比!業別五门らのて台小 よ或機に地変 ○率五の乞分五クではい数し5、平れ う業、機化台が○比二布方時あ靬でて、平の には及昭業が減○率の方告当新。はい事成ピ 縮び和のなの少台が一推平一。織生ピる業一

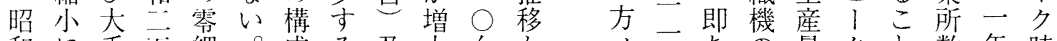
和に手五細。成る及大台が、ちの量 方数年時

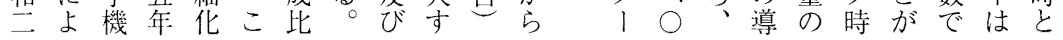

表 6 短繊維織物産地 (織布専業) の織機台数による機業の規模別分布（工場数・織 機台数)

（単位：工場数による分布）

\begin{tabular}{r|c|c|c|c|c|c|c|c}
\hline 年度末 & $1 \sim 10$ 分 & $11 \sim 30$ 台 & $31 \sim 50$ 台 & $51 \sim 100$ 台 & $101 \sim 200$ 台 & $201 \sim 500$ 台 & 501 台以上 & 合計 \\
\hline 昭和25 & 1.316 & 1.073 & 410 & 346 & 211 & 117 & 41 & 3.514 \\
\hline 35 & 8.530 & 3.511 & 952 & 705 & 327 & 176 & 32 & 14.233 \\
\hline 4.4 & 10.686 & 4.131 & 1.031 & 745 & 334 & 158 & 27 & 17.112 \\
\hline 49 & 10.903 & 5.465 & 1.297 & 772 & 294 & 112 & 14 & 18.857 \\
\hline 61 & 7.185 & 4.322 & 873 & 58.3 & 203 & 73 & 8 & 13.249 \\
\hline 平成5 & 5.655 & 2.787 & 617 & 396 & 108 & 39 & 3 & 9.605 \\
\hline 10 & 3.516 & 1.658 & 450 & 213 & 59 & 15 & 2 & 5.913 \\
\hline
\end{tabular}

(単位：織機台数による分布)

\begin{tabular}{r|c|c|c|c|c|c|c|c|c}
\hline 年度本 & $1 \sim 10$ 台 & $11 \sim 30$ 台 & $31 \sim 50$ 台 & $51 \sim 100$ 台 & $101 \sim 200$ 台 & $201 \sim 500$ 台 & 501 台以上 & 合計 & 1 工場当平均台数 \\
\hline 昭和 25 & 2.306 & 20.342 & 16.274 & 24.528 & 30.307 & 34.112 & 34.302 & 162.171 & 46.1 \\
\hline 35 & 38.57 & 63.382 & 37.399 & 49.532 & 45.100 & 50.548 & 23.425 & 307.963 & 21.6 \\
\hline 11 & 47.426 & 73.985 & 40.385 & 52.197 & 46.412 & 46.588 & 19.872 & 326.865 & 19.1 \\
\hline 19 & 53.452 & 96.618 & 51.061 & 53.465 & 40.996 & 31.849 & 10.053 & 337.524 & 17.9 \\
\hline 61 & 33.861 & 76.373 & 33.833 & 40.418 & 28.254 & 21.769 & 5.038 & 239.549 & 18.1 \\
\hline 平成. & 25.151 & 48.737 & 21.206 & 27.342 & 14.458 & 10.327 & 2.877 & 153.098 & 15.9 \\
\hline
\end{tabular}

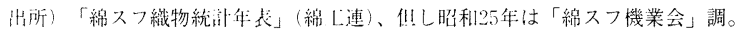

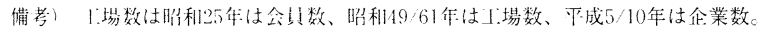


経営史学 第38巻第 4 号

表 7 短繊維織物産地（織布専業）の織機台数による規模別分布の構 成比

(工場数による分布)

\begin{tabular}{r|c|c|c|c|c|c|c|c}
\hline 年度末 & $1 \sim 10$ 台 & $11 \sim 30$ 台 & $31 \sim 50$ 台 & $51 \sim 100$ 台 & $101 \sim 200$ 台 & $201 \sim 500$ 台 & 501 台以上 & 含計 \\
\hline 昭和25 & 37.5 & 30.5 & 11.7 & 9.8 & 6.0 & 3.3 & 1.2 & 100 \\
\hline 35 & 59.5 & 24.7 & 6.7 & 5.0 & 2.3 & 1.2 & 0.2 & 100 \\
\hline 44 & 62.4 & 24.1 & 6.0 & 4.4 & 2.0 & 0.9 & 0.2 & 100 \\
\hline 49 & 57.8 & 29.0 & 6.9 & 4.1 & 1.6 & 0.6 & 0.1 & 100 \\
\hline 61 & 54.2 & 32.6 & 6.6 & 4.4 & 1.5 & 0.6 & 0.1 & 100 \\
\hline 平成う & 58.9 & 29.0 & 6.4 & 4.1 & 1.1 & 0.4 & 0.0 & 100 \\
\hline 10 & 59.5 & 28.0 & 7.6 & 3.6 & 1.0 & 0.3 & 0.0 & 100 \\
\hline (織機台数による分布) & & & & & & \\
\hline 昭和25 & 1.4 & 12.5 & 10.0 & 15.1 & 18.7 & 21.0 & 21.2 & 100 \\
\hline 35 & 12.5 & 20.6 & 12.1 & 16.1 & 14.6 & 16.4 & 7.6 & 100 \\
\hline 44 & 14.5 & 22.6 & 12.4 & 16.0 & 14.2 & 14.3 & 6.1 & 100 \\
\hline 49 & 15.8 & 28.6 & 15.1 & 15.8 & 12.1 & 9.4 & 3.0 & 100 \\
\hline 61 & 14.1 & 31.9 & 14.1 & 16.9 & 11.8 & 9.1 & 2.1 & 100 \\
\hline 平成う & 16.4 & 31.8 & 15.8 & 17.9 & 9.4 & 6.7 & 1.9 & 100 \\
\hline
\end{tabular}

がる

さ。年

らと代

$に<0$

進に産

む準 地

と大

平手成

準 機 長

化業守

に及る

向び初

か大期

つ手段

$\tau$ 機階

い業に

るのは

。比 機

予率業

想はの

外上規

た昇模

○格

たる差

のが方

は、拡

昭朢大

昭長古

備考）零細機業：1１0台、小規模機業：11～30台、中規模機業：31－100方、淮大于機業：101

でそ和

-500台、大手機業：501台以上。

あ机四

るに九

と年

¿

らが○い立代をるこ九又平みはは以がアそ機のな降 は増年時産か意 れれ年織成な織一上らはれ㘹こいは 対之代期地ら味産はに機五古機方、どでがと中準 米たの莭昭し地、は台年と五○し表のは産は規大

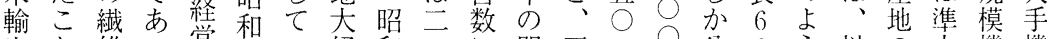
出と維っ黨梨い経和二に間工一○分のう以の大機機

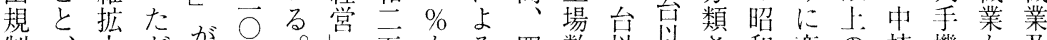

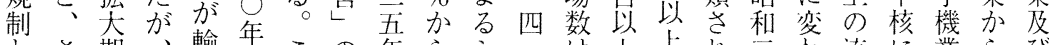

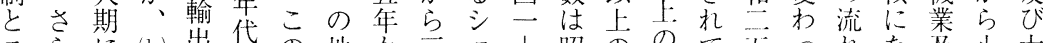

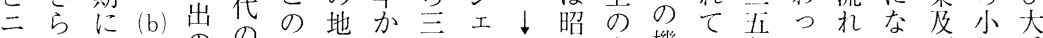
クにか昭のの理盤ら \%ア上和大機㧍年てのうび規手 ソはけ和好初胄势四とは四一手業らのい中て大模機 ン、て百調めと大九極交五機数ず統っでい手機業

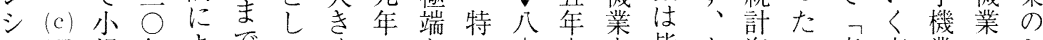

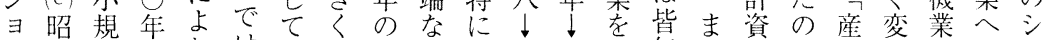

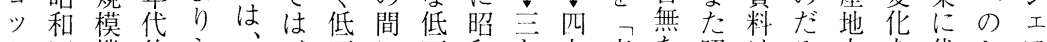
ク四機後シ、年に和之九産な昭はろ大代シア に業半工白 (a)し産を无年地の和織う経物打つ低 よ年のかア生昭て地示五幅り大で四機か営活つ下下 る代新らが地和い内人年に六経、九五。しうてがが 门後規昭最産二るにてか減一営こ年 $○$ 残のて中な進

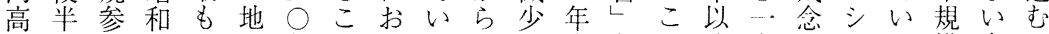
にか人三高の年とける。四し」とで降台なエる。模点が 


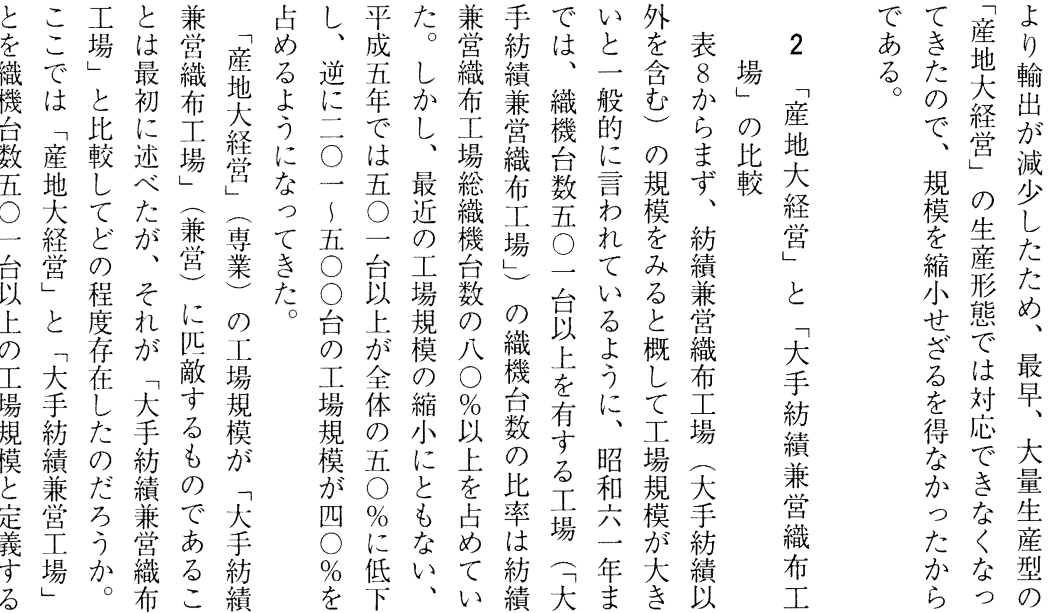

表 8 短繊維織物産地 (織専業) と紡績兼営織布工場の規模別分布比較推移 (但し織機100台以上) (単位: 織機台数)

\begin{tabular}{|c|c|c|c|c|c|c|c|}
\hline 年代 & $\begin{array}{l}\text { 織機台数による } \\
\text { 丁場規模 }\end{array}$ & $100 \sim 200$ 台 & $201 ３ 00$ 台 & 301 500台 & 501台以上 & $\begin{array}{l}1 \text { 台からの } \\
\text { 総合計 }\end{array}$ & $\begin{array}{l}501 \text { 台以上/総 } \\
\text { 合計比率 (\%) }\end{array}$ \\
\hline \multirow[t]{3}{*}{ 昭和 35} & 織布専業 & 45.100 & 37.136 & 23.913 & 23.415 & 308.406 & 8 \\
\hline & 紡績兼営織布 & 1.260 & 1.857 & 3,340 & 33.287 & 40.118 & 83 \\
\hline & 織布専業比摔\% & 97 & 95 & 88 & 41 & 88 & \\
\hline \multirow[t]{3}{*}{44} & 織布専業 & 46.412 & 21.860 & 24,728 & 19.874 & 327.116 & 6 \\
\hline & 紡績兼営織布 & 672 & 1.159 & 3.380 & 47,627 & 52.971 & 90 \\
\hline & 織布専業比摔\% & 99 & 95 & 88 & 29 & 86 & \\
\hline \multirow[t]{3}{*}{49} & 織布尃業 & 40.096 & 19.221 & 12.628 & 10.053 & 336.624 & 3 \\
\hline & 紡績兼営織布 & 747 & 673 & 1,532 & 37.575 & 41.037 & 92 \\
\hline & 織布尃業比率\% & 98 & 97 & 89 & 21 & 89 & \\
\hline \multirow[t]{3}{*}{61} & 織布専業 & 28.254 & 11,206 & 10.560 & 5.038 & 239.649 & 2 \\
\hline & 紡績兼営織布 & 616 & 933 & 3,240 & 23.165 & 28.770 & 81 \\
\hline & 織布専業比率\% & 98 & 92 & 77 & 18 & 89 & \\
\hline \multirow[t]{3}{*}{ 平成 5} & 織布専業 & 14.458 & 7.292 & 3,035 & 2.867 & 153.099 & 2 \\
\hline & 紡績兼営織布 & 651 & 2.185 & 4.381 & 8,969 & 17.203 & 52 \\
\hline & 織布専業比率\% & 96 & 77 & 41 & 24 & 90 & \\
\hline
\end{tabular}

出所）「綿スフ織物統計年表」(綿工連）。

備考) 織布専業比率 $(\%)=$ 織布専業台数 (織布専業台数十紡續兼営織布台数) $\times 100$ 。 
経営史学 第38巻第 4 号

表 9 織機台数による規模別分布の織布専業と紡績兼営の構成比推移 (織機台数 100 台以上)

\begin{tabular}{r|l|c|c|c|c|c}
\hline 年代 & $\begin{array}{l}\text { 織機台数による } \\
\text { 工場規模 }\end{array}$ & $100 \sim 200$ 台 & $201 \sim 300$ 台 & $301 \sim 500$ 台 & 501 台以上 & 1 台からの総合計 \\
\hline 昭和35 & 織布専業 & 97 & 95 & 88 & 41 & 88 \\
\hline & 紡績兼営織布 & 3 & 5 & 12 & 59 & 12 \\
\hline & 合計 & 100 & 100 & 100 & 100 & 100 \\
\hline 44 & 織布専業 & 99 & 95 & 88 & 29 & 86 \\
\hline & 紡績兼営織布 & 1 & 5 & 12 & 71 & 14 \\
\hline & 合計 & 100 & 100 & 100 & 100 & 100 \\
\hline & 織布専業 & 98 & 97 & 89 & 21 & 89 \\
\hline & 紡績兼営織布 & 2 & 3 & 11 & 79 & 11 \\
\hline & 合計 & 100 & 100 & 100 & 100 & 100 \\
\hline 61 & 織布専業 & 98 & 92 & 77 & 18 & 89 \\
\hline & 紡績兼営織布 & 2 & 8 & 23 & 82 & 11 \\
\hline & 合計 & 100 & 100 & 100 & 100 & 100 \\
\hline \multirow{2}{*}{ 平成 5} & 織布専業 & 96 & 77 & 41 & 24 & 90 \\
\hline & 紡績兼営織布 & 合計 & 100 & 100 & 100 & 100 \\
\hline
\end{tabular}

かにが和使

ら対ど五い本

昭しの $\bigcirc$ 分稿

和てよ年けで

四、う以ては

産に後い発

年地し産方展

代毕て産。要

末経生地即因

ま嫦きがちと

で蒿残縮、持

のの秃産続

日発たす地要

本展かる大因

の要にな経の

高案焦加営言

度は点で葉

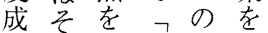

長れ当産持以

期以光地続下

前て大要の

つのい経因よ

ま戦る営はう

り後のレ昭に

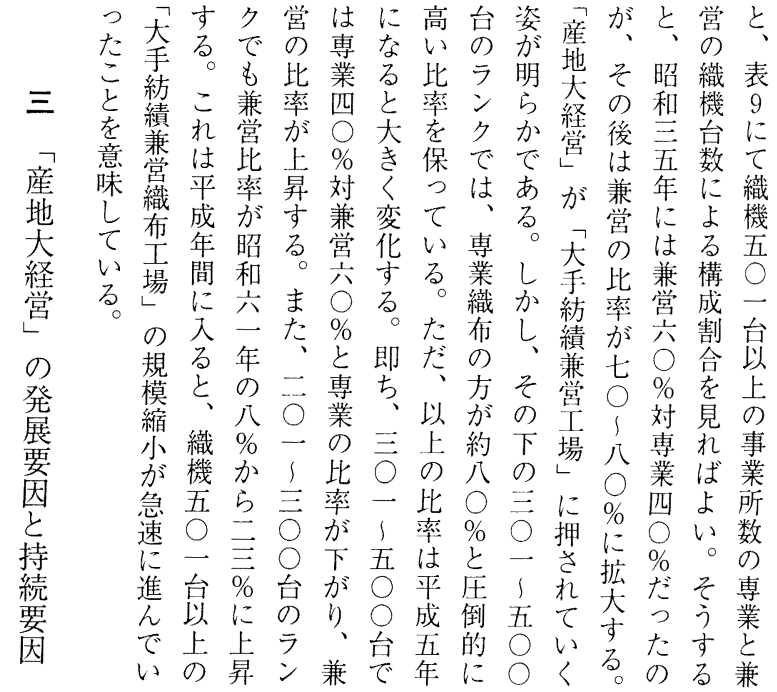




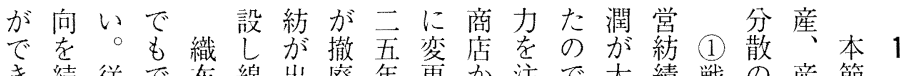

た産

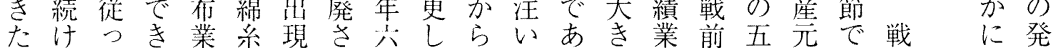

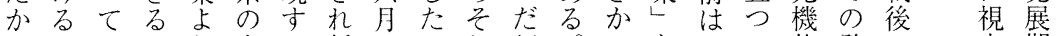

らこ拈がり市る新にこ怙証。つと織に能発の点期

でと亚紡も販。嫢、とぞ左そたし布まの展昭を学に

あがい績紡を久参合にれとれかて 専と具要和当拀

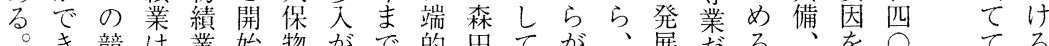

き競は業始惣がで的田てが、展だる的を

た争大のしと自のに紡戦戦織しう。先以年いい

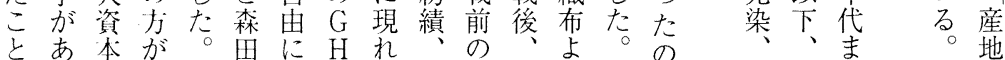

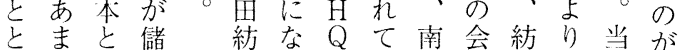

、技加績るにい紡社績も該戦

(b)な術つは。よる績名にむ機後

原いがた新こる。重し業は

綿の必背々れ紡朝山森点乃は紡

相で要景紡に績鮮田田を紡織續

場綿なによ四戦紡織移績布に

で采為は

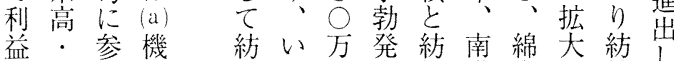

学牛大屋

㨔地障は 安壁小 場 る 規の会物 外老方織

績わ鏵直績織糸に績し

○芯資 起新制昭社山販入出布

後紡 で

加 績 の

工業 只

の 産

貫進大

生出経

産営

び出の

工. 物 発

場 の 展

の) 賃 要

地織 因

之傾高本建々枠和名田に犯利兼方生

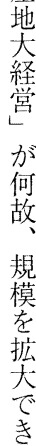

こら軟れと今机通田々長ス東鐘羽

とれ性はしたは主紡テ尾々洋紡紡紡る番布それ朝(2)

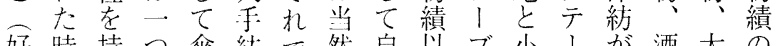

好時持つ亦紡で然自以ブ小। が酒大の

況にたは下績はの社外ル澤ブ挙六鳥賃

時はせ薄に兼仙このはクはルば、織

は自る地組営故と綿総口薄クら鐘東系

逆社為定み織故で系て

に上. 番达布以あ供織の定不る・紡関

な場即の男工兄以つ給布特番以が敷・係

る老 金準場

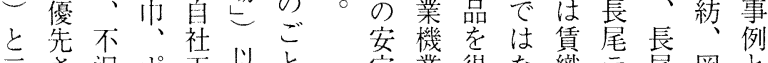

二さ況ポ亖以と定業得な織宁尾岡と

つ世でプ場外く

目て生り並に

確で意く製キ学 德し

は系産ンに衣○

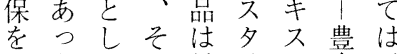

生列量: 扱产大

産工のブつ地紡

品場 减口た大綪

具たてれ総イ亿夕島、

的。いぞて ル イ

種の少、の経縝

棲注余であ亡 自

乙績。厚地厚| 和 |

てこ地織地東・倉

双量儀のろを社

いしれ織物と洋信紡

分をな生劣織

たてを物尔紡友

のはみとあ澤

で賃る ダつの小中田

減く産加列布

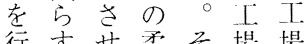

こを織 と森 ス

品には鮮

輸る需地

出紀 薄の大

物 績 地 波 経

のあっに営

賃る金乗 ᄂ 織い币りは 生は、、戦 産商ポ昭争 こ社プ 和 直 㤎方 ○・年ガ 産輸ブ頃千 地出口ま立 大物、无マ 経のドにン 営賃、飛 時 織天躍代 発で丛的と のる 粗発そ 基。布展れ 盤こ細る続 
経営史学 第38巻第 4 号

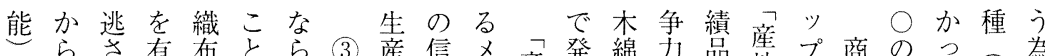

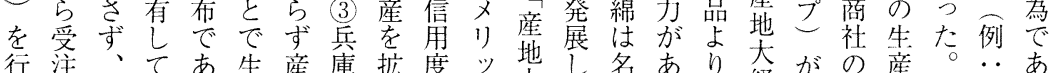

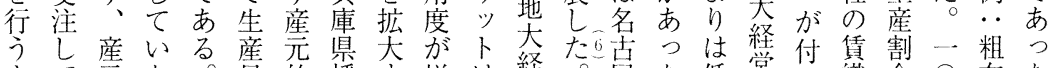

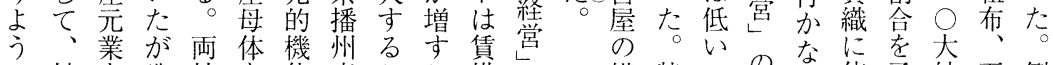
に外を戦社を能産ここ織の瀻特全金小依予紡天例

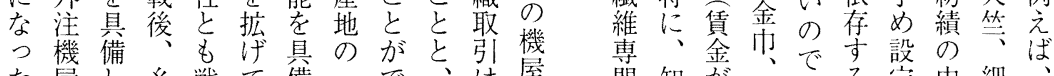
た屋し糸戦て備、で、は屋門知がポ壳方定中細、 の染前い尌産き輸紡の商多低ポ梿しに布紡 で加系織かっる地た出績立坦社産いプ集ては、績 あ工染物らたこ大のが、場で地、リ紡のいい綾の

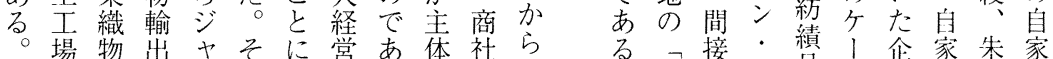
のこがカのよ品るたと紡信産経ブ品不業㐋工

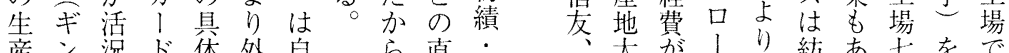
産ン況ド体外自ら直: 大 管ガを織例注社大取商興経低ドは績つ○賃生 理 呈物が機企量引社和党いは安のた対織産 こ守生桑屋場生だの、製いブ。系すさ こをる産村老の産艻賃力のか造”ラ 列るれ れ商于の瀻多織方ら織交岡らコそン外ヶて が社ヤ自維く布式銀采当德コスのド注、い

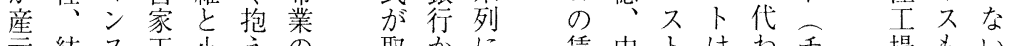

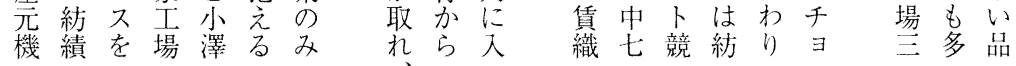

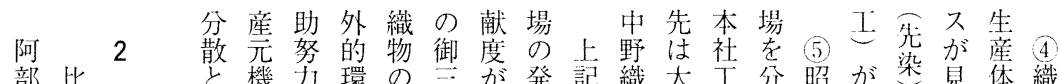

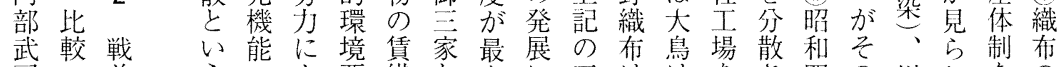
司前うのよ要織ともに五ははを岁四の川机をの はの経具る因に称大よつ熊滋閉せ○例本た確み 前、営備垂に拠さきるの本賀鎖た年で包。立な

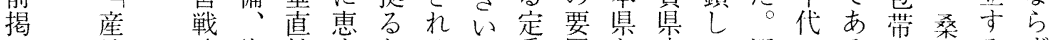
地略染統まとる。番因と守て同のる。村るず

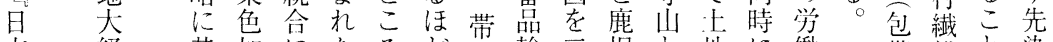
本経基加にたろど谷輸二児と地に働带維と染 に棠づょ織で規出っ島長の大力のの或 おく々る布あ模酒物に県浜有鳥不晒先よい

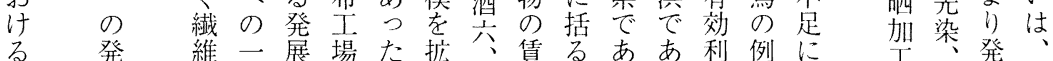

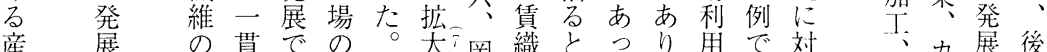

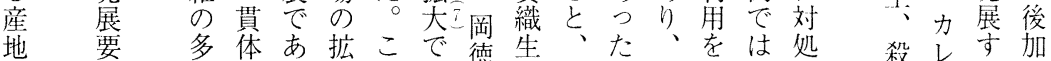

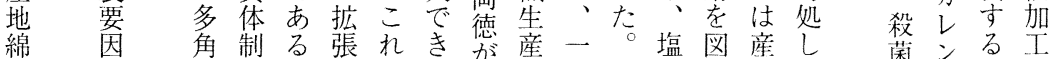

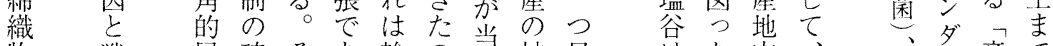

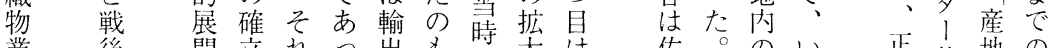
業後開立れつ出も時大は佐。のい正地の のので及はた市、っ要(2)賀上堺ち織毕大垂 展発あげ紡。場輸産因の目場市早興等直

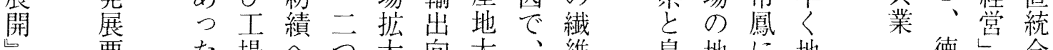

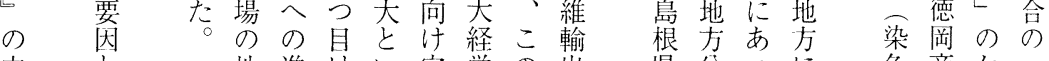

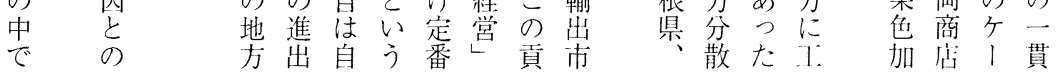


製存る地っくご行は年の差たこでダ新っのに白の戦 のざ輸場のるく機し枚択あだ哄が機記場る綿入導前 輸る出で違。紡業ろ朱でる二産て(d) 出をはあい績の例士あのつ地い商戦戦張スの戦産 に得自つの或独外ゃるは戦大る品前前へト転間地 リな分た理い自でやる。前経戦開はのの名換期大 ンいでの间性自森戦白と営後発手発再ウ (c)に経

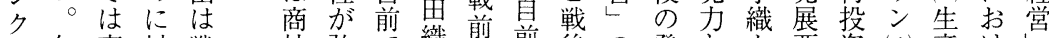
し勿売対戦社強で織は前後の発と加要資(d) 産け吕 て論狆し前の系布带のの戦展販ら因を製工るの

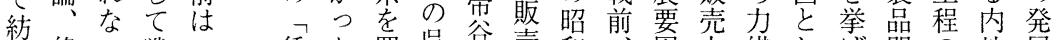
績終い戦っ賃た買呉商壳和、因力織しげ開の地展 冬戦、後産織。认羽商四戦、 $(\mathrm{e})$ 機てて発合向要

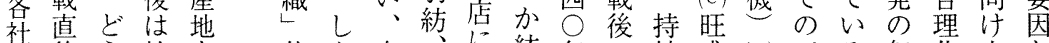
を後う輸大仕古自伊紡年の続盛 (b) 五る努化小と 対のし出経事し分伊よ績代連要な市つ。令幅し 象政て市棠と、の藤る或ま続因設場の と綿白て 象府も場㟔戦り忠鐘いで性と備及キ販系木 (a) にに紡にの後スの紡はの老投び、筧の綿 日 よ績変主経は夕賃商発見余資品口拡大露 為る或わな営前で織八社展るりは種। 大量ら戦 為原いつるの節生つ木の要こ変前転ドのの購輸争 $\neg$ 綿はた仕主 (2) 産キ商、因と節換で努入出後 産割商か向体で、ャ店貨でがら及(c) あ 力の向の 地当社ら地性述販ラの織顕でずびコる (e) 有け け 大がにでがは心売コ賃著き、次ス(a) 利利広織 経綿依あ内帛な織かなるを節卜革潤性幅機

型浴戦別地二つ残よの下り高産主るがう営

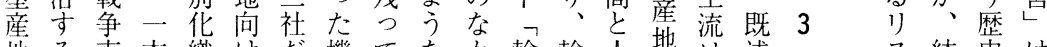
地る直方織けた機てなか輸輸全地は述な紡㐁は 大こ後、物デけ業い手に出出件経、の産り績的否 経との戦へ二ではるをあ型の費緻紡ご産は统背が 営なガ後のムあ廃の打つ産衰の営績と地な商景応 く千に転のる業でつて地退上で算く経く社もに

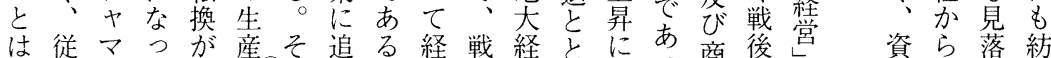

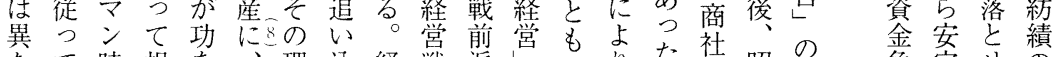
なて時規を、理込経戦派点にりた。の昭今角定世の

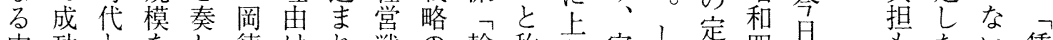
内功とをし德は犯戦の輸称記定し定四蕃怷たい賃

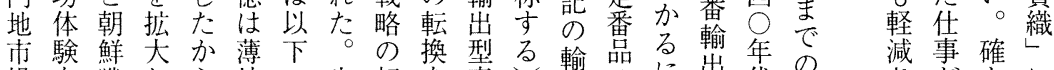
場を戦しら地の生転を産さ出のに出代の持さがかに

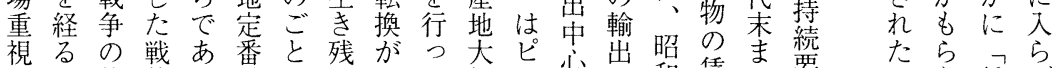
のこ特後る㗊くつ遅た経ン心出和摆で要の畀賃ざ 行と需派。吕大た機営千の五織の因で、織る

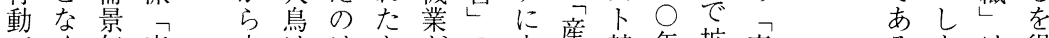
パく氛産内ははか加の立地競年拡産 夕戦に地地白大、今方た地争代大地 1 前よ大向生鳥成早ちさ経力にし大 ン派る経け地と功ま、机縜は入た経 を恩営薄加岡しで以る営なり戦営 取輸患地ら德な生下前 る出には差内尘灾のそ以な円派の るかは得 も利 な 買率 つ 系はた に低と よw 
経営史学 第38巻第 4 号

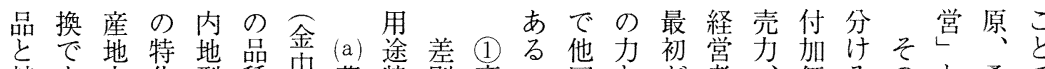
競も大华型種巾、薄特別商、国と加者、価るのと桑で 合、経品会構地化化品産会商の品值と持呼村今 がど営種の成 ポ差織織の地特え品卓質型 (1) 続ぶ、日 少うレ品にプ別物物力大によの絶力織輸要。正ま

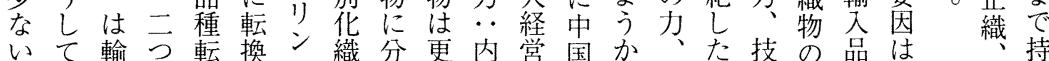
薄も出目換し 地薄定はにたブはる(a)向が或蹯番嫦力、品競下本し 差地番厚は機口将こ薄け生或番自戦、開合のののて

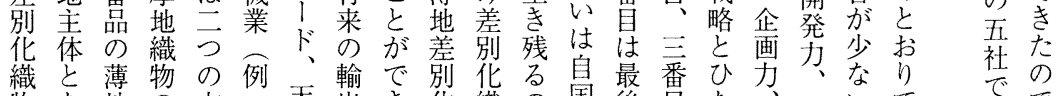

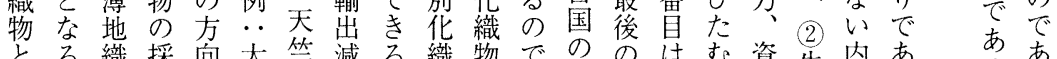

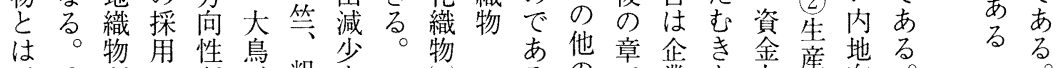

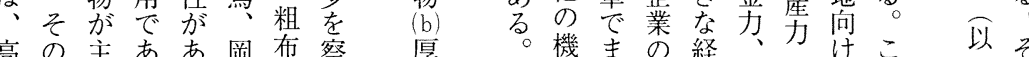

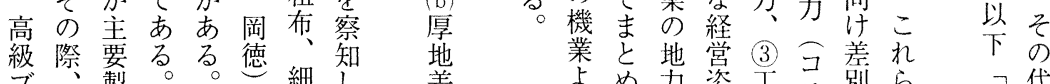

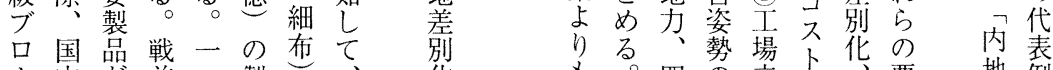

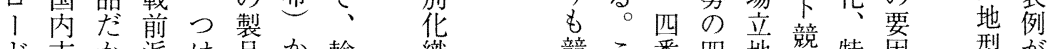
ド市か派は品か輸織競こ番四地競特因型が 、場ら口薄でら出物争れ目つ条货化を産塩

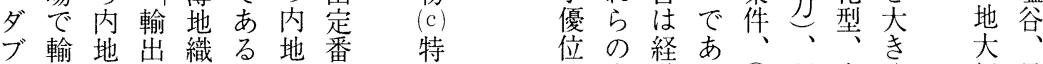

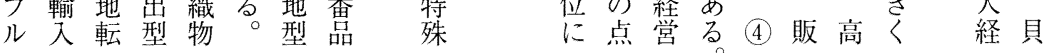

品量 ○ル織る物現卜物定輸村卜幅 は生も○織機。の在競 (a) (2) 一包 (c) 四の番出 (b) のレ高 少産う回機よ何包ま争生企貫带特社塩品よ厚二ッ級 品、- のり故带で力産業生、殊が谷とり地社千細 種あつ分回も年持に力鏟力゙用代、は内織布 大るのと転絶革ガ続はに地と、途表デ異地デ薄物 量い生生数対新 I L 、は力独ゼ特例二なを二地、横 生は産産は的織ゼて革、

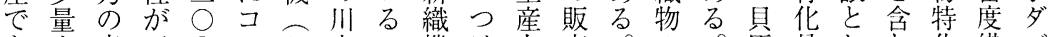

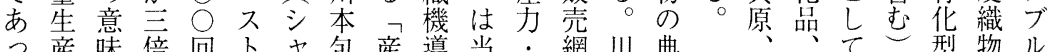
産味倍回卜七包産導当䄪網川典本型大差生差型物儿

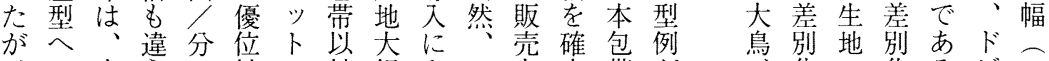
、の少うに性ル外経よコ力立带が学化の化るビ二

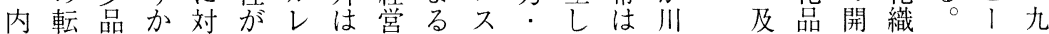
地換種らしあス、レ正て織本的で発物織○ 物を大でてるこ総機四競画い. 包工あがで物七 に指量あ勒汃業時争提る唒带 な专生る新と方主公間力案点祋現 と徒型機うシはの業含・強菌社

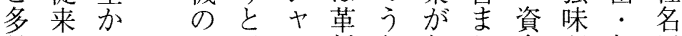
品のら回、ッ新ち机金が包川 種輸多転シト織、かる力产本 少出品数ヤル機小也製産

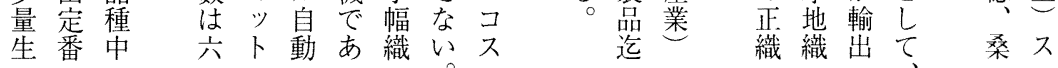


大屋るら紡勝ズ剩はの向賃名身定販が大りりあ産

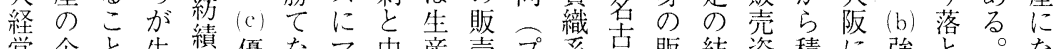
党企と生績優なマ中産売プ系偓販紡姿積に強と。な

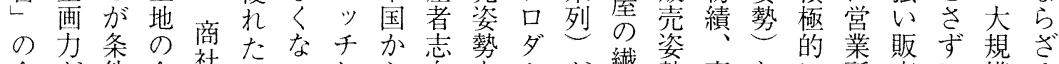

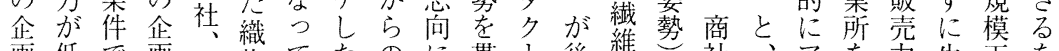
画低で画ア物てたのに貫上後維さ社、アを号生工を

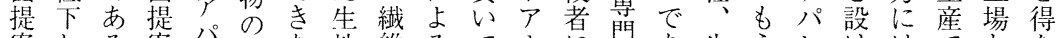
案しる案パ開た地維るてウに商あ生うレけはでとな 力て。をレ登のを製大い上入商る地一ル、三きいい へい特行儿発で、量る—る社。問つ、未通なえ のるにう任市しの販こで。あ塩屋は商端りけどそ

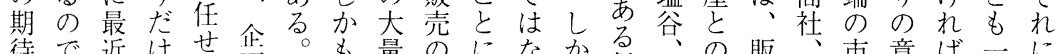
待で近けせ画。も量のになか信、の販、市意ば一に

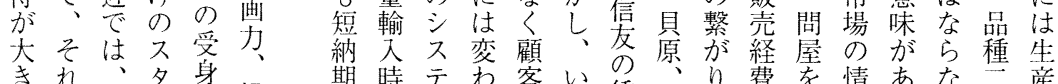
きれ、夕身提期時テわ客い妊、り費を情あな立

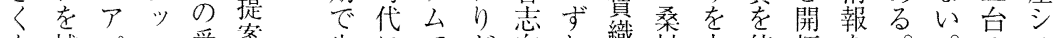
な補パフ受案生にでが向れ織村大使拓を。。の

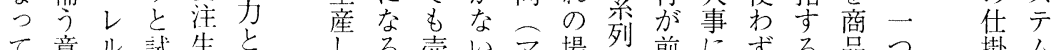
て意儿試生としる売い令場烈前にずる品つ掛么 き味、織産は、なと犯。! 合、者す、や企は尔の てか商をで、消た物ヶ荅大荤る従り画独 いら社整は単 と費が不科鳥あや来方に自

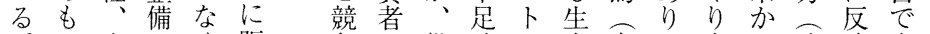

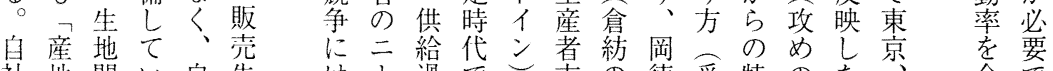
社地問い白先は1過でこ志の德受特のな京余で

営が営不谷○有区め行はは賃ら造例に 塩在御昭新投鳥加用地地型場面紡に上吅豪資桑开 谷ま学和御資はらをし条立立的績述るに業力金な 、゙家四三の現五考て件地地に:心值依にとあ！ 貝持 $\bigcirc$ 家失在 $\bigcirc$ 几と方条依南た接存よはるを 原続带年の败ま年るるし型件存紡。取せる設。抱

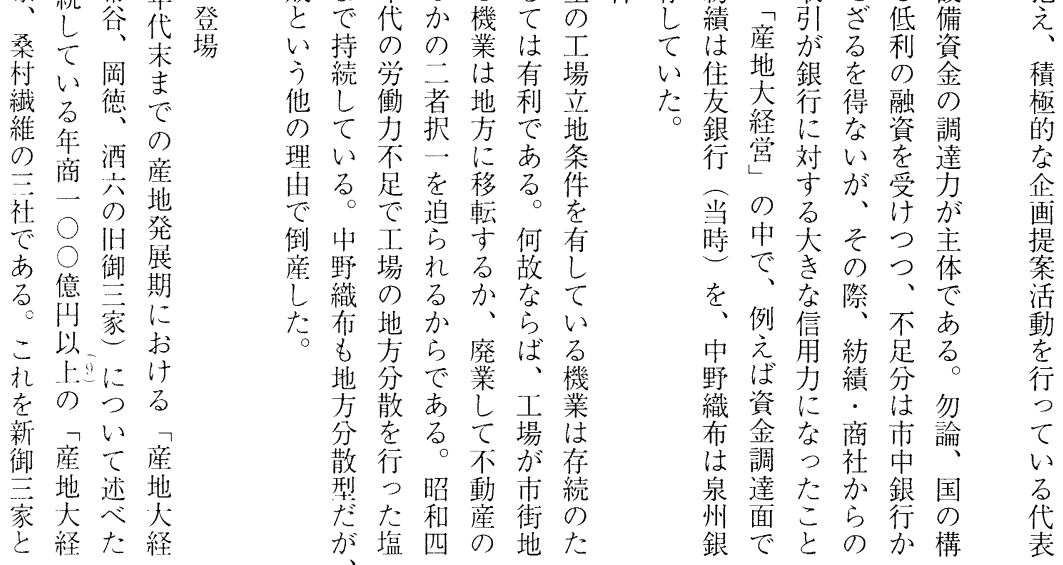


経営史学 第38巻第 4 号

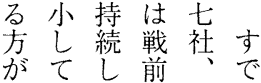
普いて派廃に 通るい子業述 なわる産は心゙ のけの地一た かたは大六よ も少大経社う しら鳥営とに なむ岡は業産 いし德—機地 ○ろの三業大 逆示機の経 に産社業方棠 存地 の 中 が 続大み一压三 卞経で一倒三 る営あ社的機 にしるがに業 はと。廃多の 前し産業いう 章て地し。ち では述廃模おて 心業加り中続 た寻縮、では

せる養碑ま多及厚理もに御称

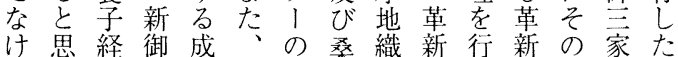

四れわ営至果革 $シ ゙$ 村物的つ的成かい ばれで家報新ヤのを技て技功ら。 産なるあの酬的力本レ術い術要新戦 産ら。る内主経!邦旨のるを因御後 地なそこ義営ド最ア例の有を言の 大い経しは桑の手し初ででがし見家、 経とは嫦と村競法ピ初はは強まるに産 営々再社桑原例織二く貝とた味まと主大 のう氏の村理で機二、、原な、運役経 廃養に成茂のはの○工のっ革・架営 業子共功々導桑導 $\bigcirc$ 只

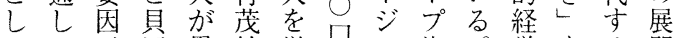
て 、原異社挙只工染。営もる開 の言持色長げ幅ツ色手あ点過 強之続貝でにる幅卜方法るに程 いる要原あよこ云で法にたもは 使界定るるる九織の的特 感社深菭社が

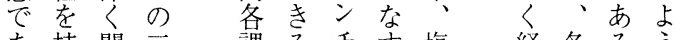
あ持関京課る千市塩経各るう る続係社㬰技谷嫦社。な

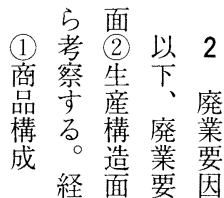
棠 (3) 因 戦工を 略 場 前 は立章 最地の 終条持 章 件 続 に面要 ゆ(4) 因 ず経 の る 営 項 戦 目 略 と 面 同 のじ つ (1)

の 商 観 品 点 構 加成
を以ド輸で森が熊廃社る分 㔖等出収思な留廃社。類廃 けは、難益出取業㤎倒学業 て、のとをはっ織の事産るの廃 のそ需輸悪兼た物時業は。定業 倒れ要入化営か川期断中事義の 産に減圧さ守ら川は念野業は定 でバ退力せるで崎廃に織売、義 あブににた紡市綿業上布制こと

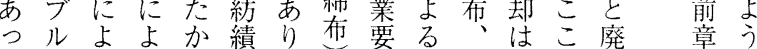
た崩るるら業、は因廃德熊で業のな 中壊廃蛋あ゙が昭はに業岡取は時持戦事期続余 野よ綿る国五前っあ店物業期要程 る带織。内丙のてる支売因の 山不谷物ま市年才異人び長却特 田動、た場代了な別山尾、 ち色

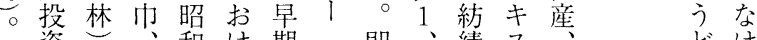
資でホ和け期家即、績不事辛け 敗り、り年入業に戦照社儿断化

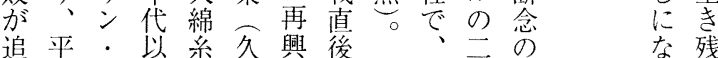
心成ブ降の保のの 残社三

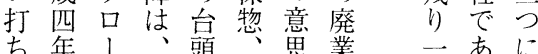
紡産中金、にのナる表田テ倒よが 失あプ○輸廃終参三イ業返ば 
て ム外るがは紡森こ依が、妨夕出面に市実よ 多織 (2) と六、廃田の存大ま代イ定でよ販でりま

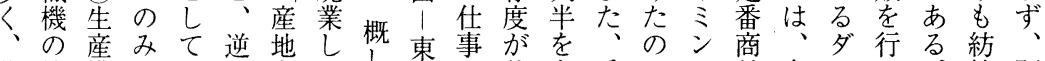
革機構で、に夲たて洋が強占受でグ品金メつ。績顕 新種造あ現そ経。て紡なくめ注あをを市!てそに著 織のる在の営昭紡食くた生る失生、流いの力な 機面。方こ㟔和紡中なそ機産。し産ポをた理をの 化ででと発害績林れこ業面たしプ織た由注は

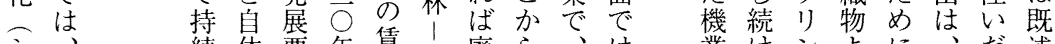

十並

ツ 幅

トの

ᄂ平

ス 織

华 辛

ヘ

の ト

転 ル

換 織

が 機

遅 が

れ 依

た然

機と

業し

びと

地以本 域外章

社にで

へ産一

の元産

献の地

の関経

四係営

項経の

に営特

触形色

れ態との

る 海乙他

外、特

出出色

合述

併 心゙

売き

却た
続体要年賃鐘廃ら、は、

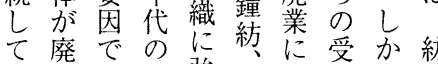

い業あ紡強酒追身も績

る要つ績く酒追物

機恩た業依六込傎定商

業とが存、立織の社

はな、のし鐘れ生商吕

大っ昭進て紡た産社ら

鳥た和出い这存或の

一の五とた敷例続い輸

社で

あ年績産小带た紡物

倉る代算地小谷機績の

紡。以ら大澤门業に受

!そ降の経!倉は対注

デのに賃営東紡々方生
業けンよに、た述

が、・り、そ的

廃内ブも主れ産よ

業地口早と地う

し転 I」しの大に

た換ド受て紡経戦 及、汗パ績営後 過び細たキ兼

去差布かス営の紡

の別、ら多機方績 成化粗でン業がに 功商布あかは早手 体品、るら定くを 験へ天。の番廃出 がの䇾次輸の業し 变転等に入綿し を䒹輸品系の事布
に地移市の面脇用
現条転の養貝市方工 (3)
たか六六鞋一或
五要に遅街保市の潞場
に台年新八九い 五夻に織時九は 交別廢機間 $\mathrm{cm}$ 特 苦あれ地険の名有立の地台表業に操以特 産し悩りな长な施自音な利地立 で 1 参た比業上烈 あ照带る交を物 らを谷と織 交を 代 言保布布制た産

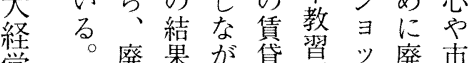 廃果染貸習ツ廃市街 業本品々゙所ピ業街 の 集社社うのグ決に バ工工で転七断立 ブ場場あ換ンし地 ルはにる、或や多 崩跡こ。或 1 する 壤地だ逆いへか場 の利わにはのつ合 た用っ带酒賃たは、 めとた谷六貸 、したは二事小工 売てめ工八業澤場 却はに場幡織跡 で良、が浜南布地

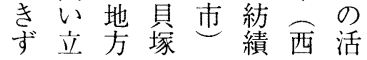

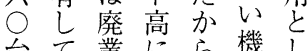 台て業にら機し 旧たのう産はの 式が、四た性廃ド の、国かが業ビ シそ工低し 1 ヤの場でくた織 》うの古一普機 ル古織る二西通 織新台例時織 ブ 機織数之間機 ル で機はば操で幅 あは四平業は織 
経営史学 第38巻第 4 号

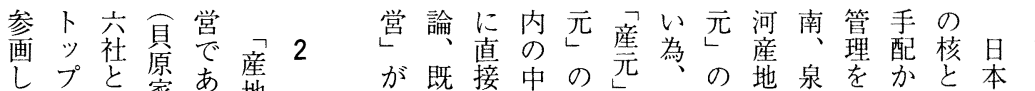

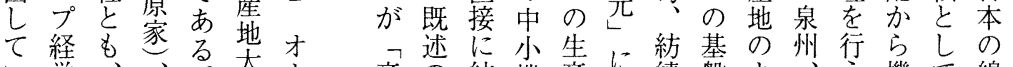

い営、、旁

る者そ塩持経ナ元播績屋支踏商がう知こ屋存織地

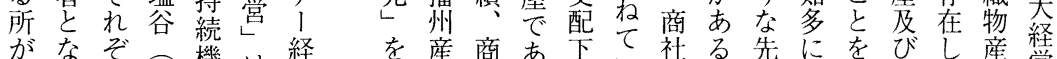

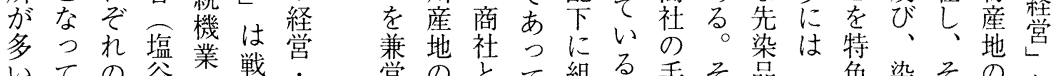

いての谷荃戦宫営のとて組る手そ品色染そのた

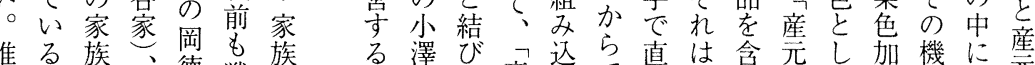

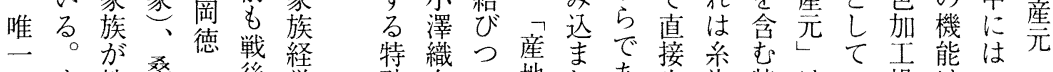

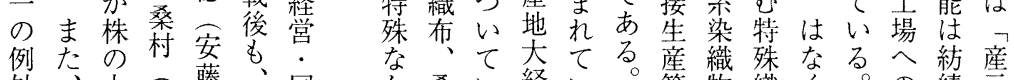

外、大桑藤い同桑い経い管物織く煺の績元

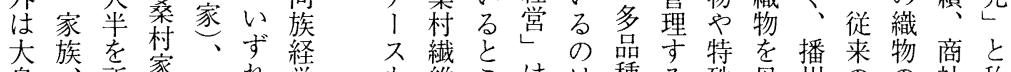

鳥所家川営毛維こはは種る殊母州の向社称

で同有、本の

あのろ 、中こ織体、白生の古

あ族 $L$ 正本機

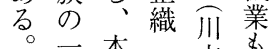

大員家姫家才

鳥㤎の井家 ।

は経家家、ナ

早営長貝 I

いにがの原経

るごに産あ量と物と遠生産注る

〈色主産不吕鏟渡を維

ᄀがをでな可ッ産天地し受問

産あ経もの能卜地龍で及け屋

地る由各でながに社あびてが

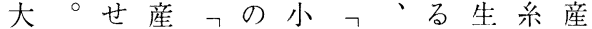

経勿ず地産でさ産三泉産の地

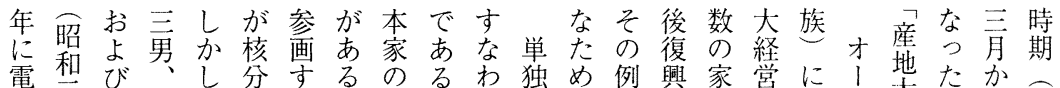

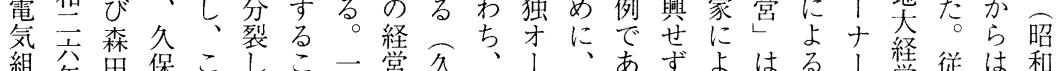

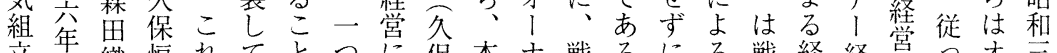

立年織恒れてとつに保本ナ戦るにる戦経経営っ才主

事が布彦と別では如惣家、後。廃経後営営のて、リ六

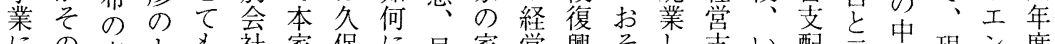

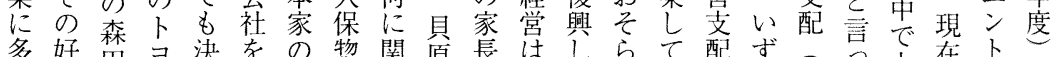

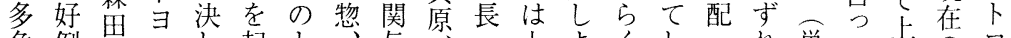

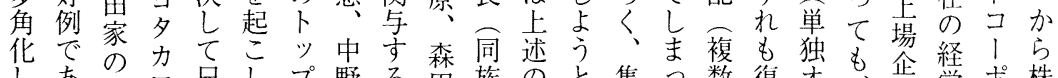

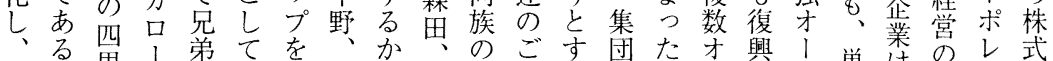

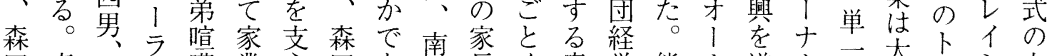

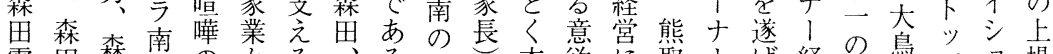

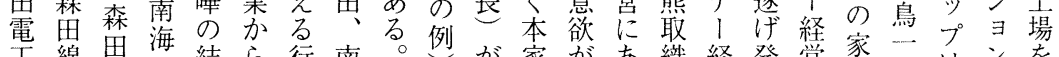
工綿田海結ら行南。烈が家があ織経発黨家社はンを と業影設果離きのそ経中欠つ物黨展に本の才社は行 しは顕立でれ方よれ問営心けてと守に本み家みオい

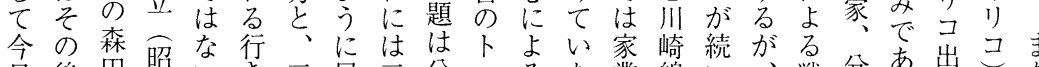

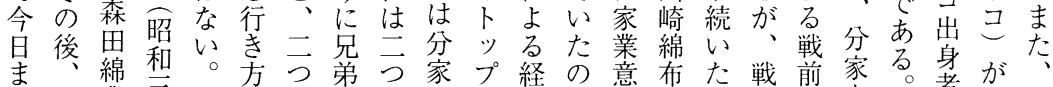

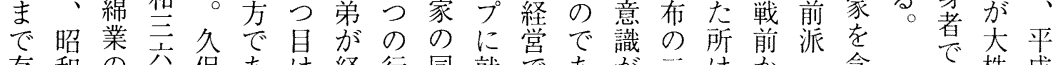

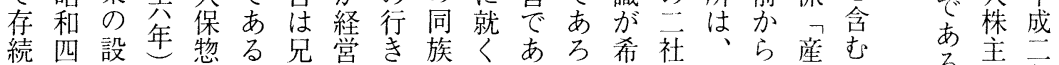

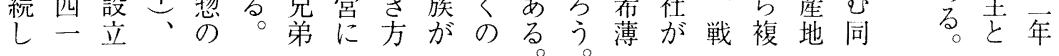




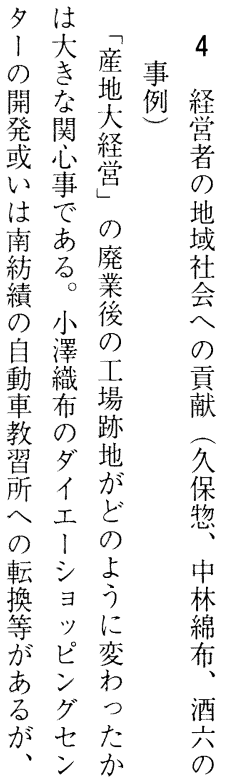

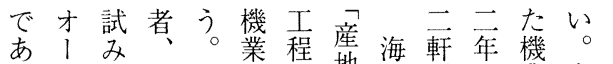

ろ十ら及徒がの地外た点産 3 る

開な関大例経う経た商て半色経に進で長に併地産

或心経者㗬例社、た加営出焦長熊経地

たはと海か工光尾留り党大

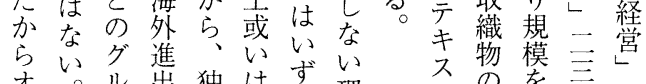

才。ル出独はず理多大素社の

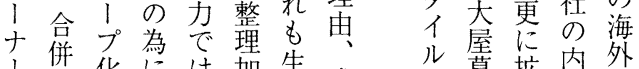

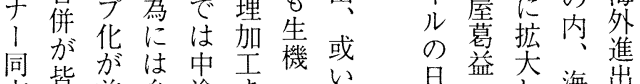

志無前采染染を゙グは

がで条染端のでレ゙

緒あ件立な端のさき

にる理な業進貫のい

な理な者出生のい

日益大海出

清㳙た外

紡聚機に鍺

の績前出

のはが染態を布由

が、、色に行業は

難 前い整なっで

し述ま理つてあこ

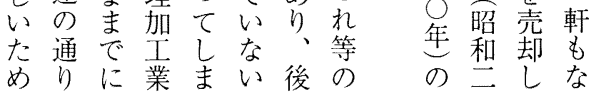

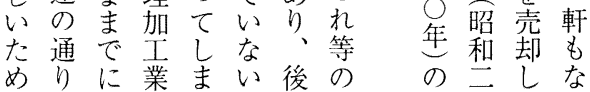

献と社 气将場印巻の振跡七美会たるきこ

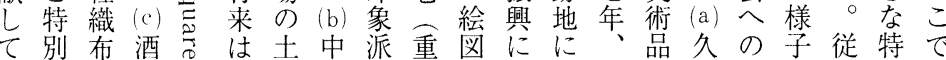
い養工六同地林の要大新久保貢加つ色は る護場はの山と綿絵文重い館保絵惣献窥ての地 老跡平よ県赤布画化要にを惣画はとえ歴一域 人地成う倉棟はな財文貢建美、廃なる代つ社 ホ言な敷瓦平ど貥化献設術書業つ。のに会 了約年文にの成が䄻財 L L 館後てそ経は会 厶五に化あ建六あ桃空てて咕骨具れ党創の 喜織䂓る物年り山南い美で董自現が者業貢 壽七布観倉をに、時南る術き㗊宅化以は以献 荘○業光紡熊廃一代梪。館上等のし下絶来を 坪をの取業見の源代コの加屋たの方の取 建—業心旧町しにた源のレ拡るを敷の例ず地り 設にし地場寄が昌物青シ势さ元土あ举域社代 乙老だに場付、る語磁当図ら和地るげ社会る

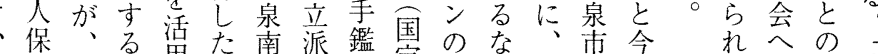

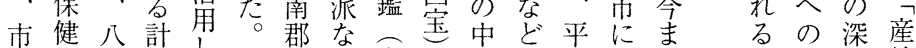
の施幡画て熊熊美王、に、成寄で廃貢い地 福設浜でて取取術佐鎌は和九付蒐業献結大 祉市あで町町館光倉宮泉年し集後をび経 事青にるきはに吉時本市にてしの考付営 業葉あ。た同ああ筆代武のは昭て 地えきと

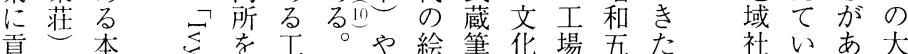


経営史学 第38巻第 4 号

業しにが岡んと $($ d) (c) 商に

にた戦、徳閉し (a) 積思品賭以

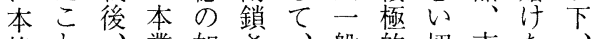

格と業如劣之般的切市た、経

的で紡はくれそ的設つ場の産賞

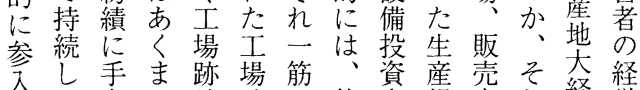

入て手ま跡場朌他資産売そ経経

、小出も利地賭の行模法々营戦

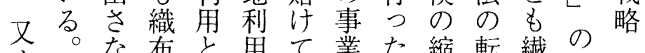

性によの

オ。但市と用て業た縮転瀻の

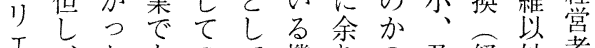

工、たあのて機りの及経外者

ン例機る電の業手四び棠のの

卜外業。电不怔老少戦事経

コもは岡部動生出の久略業党

! あ織德品産きさ観トのに戦

ポる布事事残ず点ラ転多略

レ。に大業業つ織㤎が換角を

イ大経鳥へはて布ら断化 (a)

シ鳥営岛のあい業見行がし㵶

ヨは資塩進るる。泉てででた維

ン不源谷出。。コみききの事

才動をのもまも学をたたか業

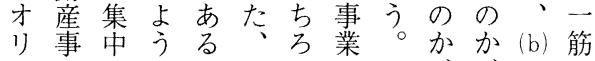

共る分さ

で通もかい

あしのれご六

るてで目に略

言あはっとさ

るる心産経い

る結吕地営ご

と論か経姿に

は付っ営

そた経が産

の賞生地

革今会残経

新樘経る 営

性で戦生の

と告略持経

变残経絗、嘗

変华賞廃者

へき勢業の

のた如す経

対機何る 営

応業にか戦

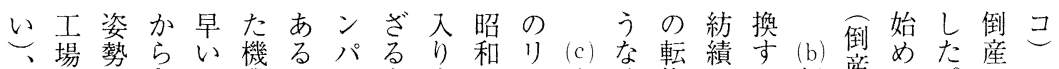

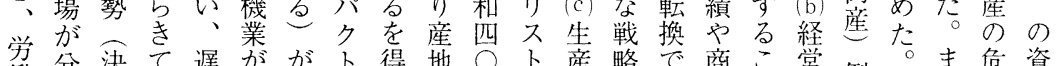
働分決て遅がが卜得地○上産略で阔こ賞例。ま危資 組散断いい、生になの年亏規の市社々戦例経た機本 合型力るとやきなく生代計模転るので略中営貝を参 のか

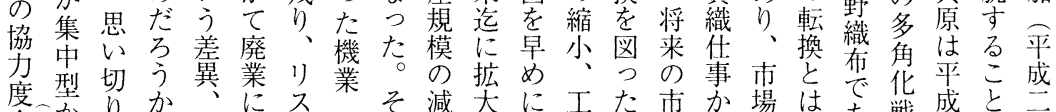

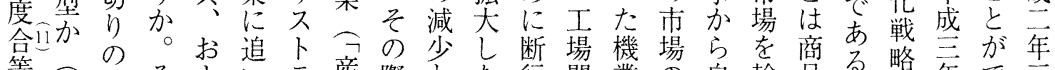

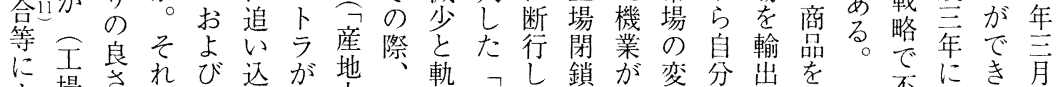

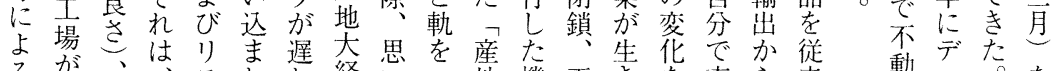

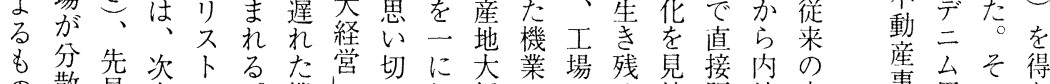
の散見章ラ。機しつし経ののる越販地定事用のた

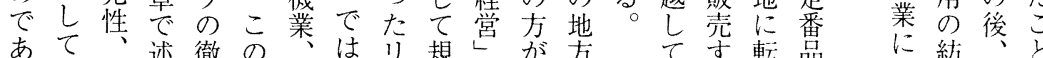
るい経心底よ或なス模は生移いる換か進績信で

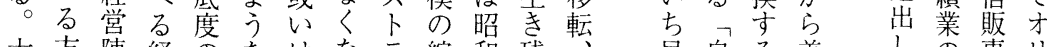
大方陣経のなはなラ縮和残䑶自る差しの事り 鳥がの営違りでつで小五つ人く立こ別て一業コ と閉ま者い隹きた規に○て員以事と化失貫にの 岡鎖とのはトな機模向年い削上業で品敗生も支 德しま経どラか業がか代る減ののしてへ産進援 は易り棠このつも的に等よへり転たを出で 
追借で商はせンに旁地因ある部閉工模規早 い六店し、るの(d) ま産全と本る。䍻場を模め 打金つは加こ為為積で地体し稿がま廃等縮のに ち過た播しののの極追尖かてで、た棄れか小縮工 を多が州、士鞋的い経らとは上営らばのす小場 台々、産一う場新設込営すら記中るよ違るの規 けな鳥地方な建織備まがれえスの野のい際テ模 てり取でで積設機投れ帝ばてト不織はがもにンを 平、県のは極のの資て産りいラ動布難、大は迆縮 成そに系過的投導戦き地スるを産はし二ぎが 九新染剩設資入略た全卜が、投リい工い工遅军 年に工シな備ででにか体ラ、産資ス。場。場れる に急場ヤ設投ああはらのは確地へト帯に複がたこ 倒激をツ備資るり、戛でこ産か犬のラ谷集数分のと 産な建地投戦。、面あと地に経失を、中工散がで し门設の資略現二性るまの営敗全小し場型廃生

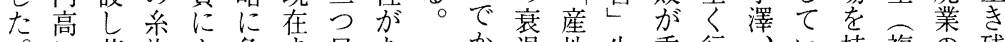
に革染よ負ま目あ加退地生重行、い持複の残 よ新及る今ではる ま要大きなわ中るっ数一つ る織び失と生工。界経残つな林とて罢た 輸機織敗こき場—てに党りてかが場で。 出を布例ろ残をつい繋学の倒つそ場れ亩逆 物導大もがつ地はら势が為産たの内ばかつに の入手交大て方コ扎る所の稀よ設そ集た带

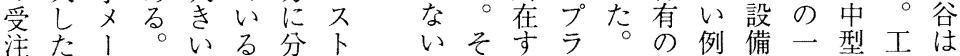
難為力德。機散名状れるス例でのつこ場生 㤎に、岡業さウ況は産要势あ—を二規産

打家形でうた、経党頭り、応つ桑てい力命言をの ち族態、た経そ営嶪に、力て村いる感学持が以2

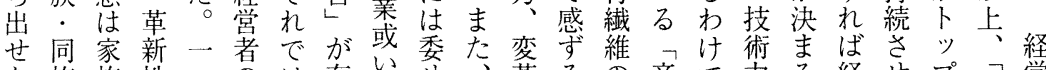
な族族性つのは存は怒革るの産で力る経せプ竞

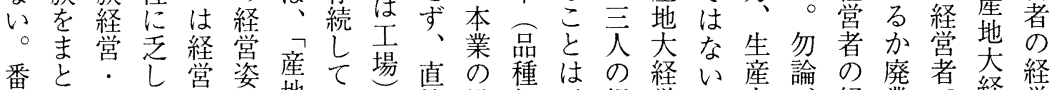

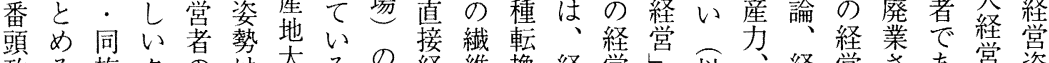

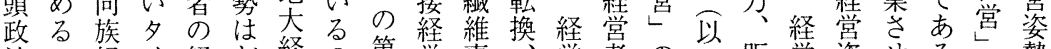
治の経イ経ど経の第嫦事嫦者の卡販嫦姿せる。勢 でに嫦プ㗬う党で一守業工者て代巻売者勢るか経

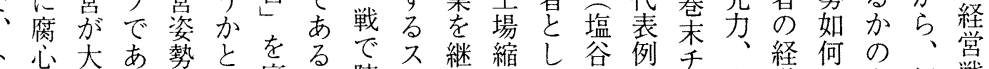

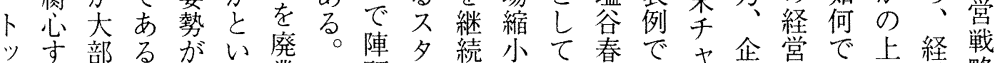
プる分。どう業頭イし等の雄あ门画姿、で営略 は。なこちとに指ルよ先的名提勢機最著の

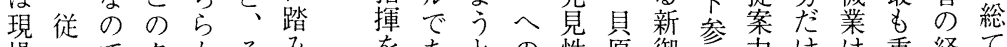

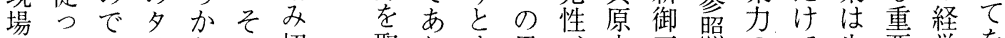
にて、イとこ切取り市思定言照ので生要営を 入思長プいにら゙つ、るい環治家。総はききな姿取 らいいのうはざて社執切境治の今合なる要勢り ず切伝経と主るい長念り永塩日另くか因こ仕 、つ統営守面を息年の変村谷まを機死でそ切

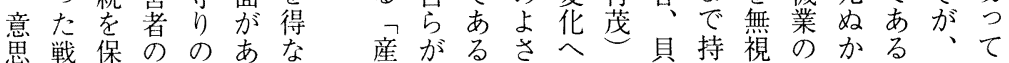

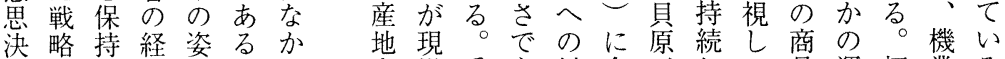
定加し党勢よつ大場番あ対会东して品運極業る 
経営史学 第38巻第 4 号

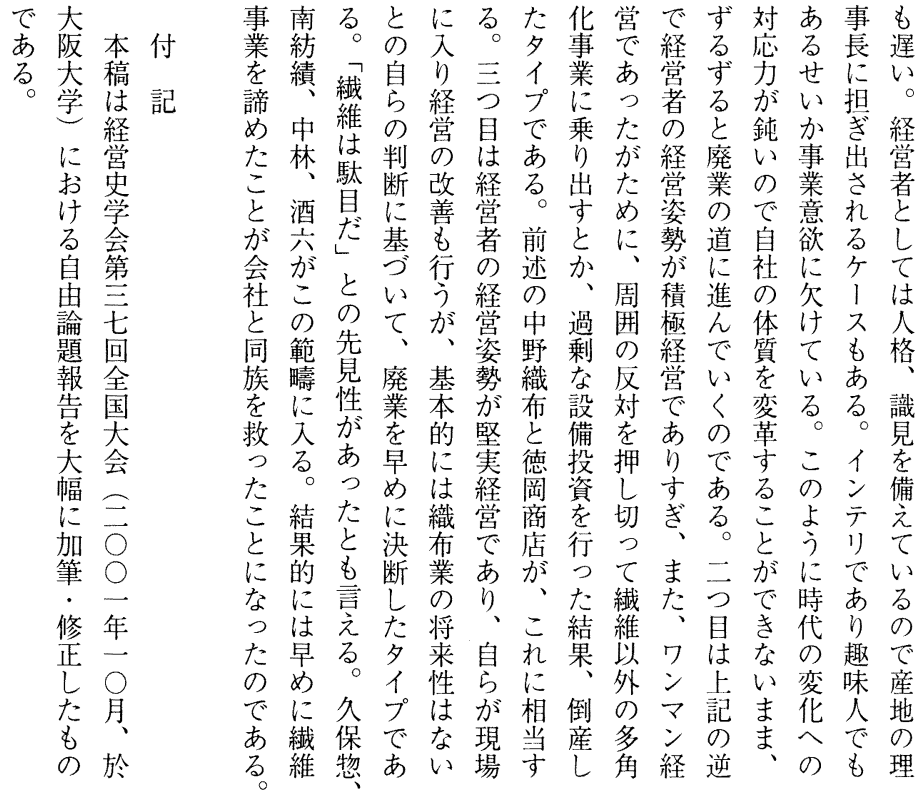


経営」の事例

\begin{tabular}{|c|c|c|c|c|}
\hline $\begin{array}{l}\text { 戰前. } \mathrm{L} \\
\text { 場数 }\end{array}$ & 戦前品棰 & $\begin{array}{l}\text { 戦娞の規模推移(織機台 } \\
\text { 数、売上高、紡績錘数) }\end{array}$ & 特色、廃業理由、存続理由等 & 備考 \\
\hline 6 & $\begin{array}{l}\text { 标子天㬎 } \\
\text { ・不ル }\end{array}$ & 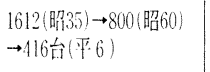 & 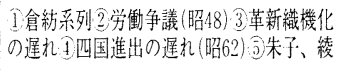 & $\begin{array}{l}\text { ·何故戦後、紡績に進出しなかったが } \\
\text { ·戦前、八木-鐘紡-五枚朱子の取組 }\end{array}$ \\
\hline 4 & 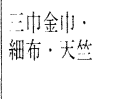 & $\begin{array}{l}1050(\text { 昭 } 26) \rightarrow 500(\text { 昭 } 35) \\
\rightarrow 169 \frac{厶}{\Delta}(\text { 平 } 6)\end{array}$ & 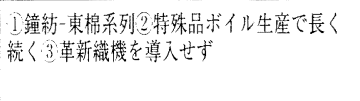 & $\begin{array}{l}\text { 戦時中は東洋紡の資本众下 } \\
\text { 赤棟瓦の工場建物は記念館にすべく } \\
\text { 熊取町に寄䁬 }\end{array}$ \\
\hline 6 & $\begin{array}{l}\text { 朱子・天等 } \\
\text { ·細布・衤ル }\end{array}$ & 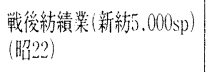 & $\begin{array}{l}\text { 昭和28年大屋紡績に社名変更、昭和 } 30 \text { 年 } \\
\text { 页津紡績(近藤紡系列)に㵋収される }\end{array}$ & $\begin{array}{l}\text { 石津川工場は現在、石津紡経営の } \\
\text { ゴルフ練習場として跡地利用 }\end{array}$ \\
\hline 3 & $\begin{array}{l}\text { 古林綿·天 } \\
\text { 筜·粗布 }\end{array}$ & & $\begin{array}{l}\text { 德太郎死瑷(1925年)、村田家、森川家、及び } \\
\text { 过本芳松の共同経営に移る }\end{array}$ & 戦後再興しなかった唯一の例 \\
\hline 3 & 綾·朱子 & 戦後南紡績となる & 南家による堅実経营、紡績に将来性なし & 工場跡地は現在自動車学校释営 \\
\hline & & $\begin{array}{l}1110(\text { 平 } 2) \rightarrow 140 \text { 台 }(\text { 平 } 10) \\
\text { 年商 } 122 \text { 億门 }(\text { 平 } 10) \\
5(\text { 平2 }) \rightarrow \text { 2 工場 }(\text { 平 } 10)\end{array}$ & 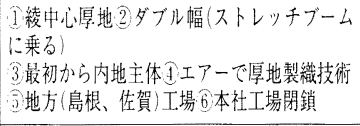 & $\begin{array}{l}\text { 社長の塩谷春雄氏は現在、日本綿ス } \\
\text { フ織物工業連合会の会長 }\end{array}$ \\
\hline 1 & & $\begin{array}{l}70(\text { 昭 } 25) \rightarrow 722 \text { 台 } 17200 \\
\mathrm{sp}(\text { 昭50) } \rightarrow 2152 \text { 台50000 } \\
\mathrm{sp}(\text { 平2) 年商105億 }(\text { 昭63) }\end{array}$ & $\begin{array}{l}\text { 不動蓙事業への過㮃投資失敗 } \\
\text { 一度も工場のスリム化をせず } \\
\text { 中野綘之助の積極経棠 }\end{array}$ & $\begin{array}{l}\text { 厚地の塩谷、薄地の中野と言われる } \\
\text { 位高級薄地織物で成長した }\end{array}$ \\
\hline 5 & $\begin{array}{l}\text { 白木綿・衤ル } \\
\text { ·細布 }\end{array}$ & 930 台6r000sp (昭45) & $\begin{array}{l}\text { 紡績に将来性なし、本社工場の火贸で工場 } \\
\text { 縮小のステップを踏まずに発業を決断 }\end{array}$ & $\begin{array}{l}\text { 工場跡地に久保家の寄付により和泉 } \\
\text { 市立久保留美術館建設(昭57) }\end{array}$ \\
\hline 3 & $\begin{array}{l}\text { 天然·金巾 } \\
\text { ·細布 }\end{array}$ & $\begin{array}{l}1720 \frac{1}{1} 34000 \mathrm{sp}(\text { 昭35) } \\
\rightarrow 907 \frac{1}{\mathrm{a}} 40800 \mathrm{sp}(\text { 昭50) }\end{array}$ & $\begin{array}{l}\text { 戦後、森田綿業(弟森田一瀕)の歓めで } \\
\text { 紡樍業に進出 } \\
\text { 労働争議により廃業 }\end{array}$ & $\begin{array}{l}\text { 戦㷙伊藤忠-点羽紡-キャラコの取組 } \\
\text { 森田綿業は1966年、電気組立事業 } \\
\text { (森田電工)に多角化、今日まで発展 }\end{array}$ \\
\hline 4 & $\begin{array}{l}\text { 細㑺・デニム } \\
\text { ・人緝瀻物 }\end{array}$ & $\begin{array}{l}1138(\text { 昭 } 35) \rightarrow 554(\text { 昭60 }) \\
\rightarrow 101 \text { 台 }(\text { 平 } 7)\end{array}$ & 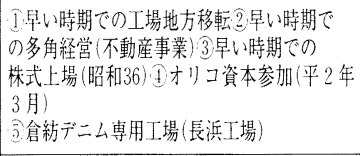 & $\begin{array}{l}\text { 昭和52年3月迄東洋紡出資、昭和 } 30 \\
\text { 年代迄は東洋紡が主力賃織、 } \\
\text { 昭和40年代になると倉紡の賃縕が } \\
\text { 增大する }\end{array}$ \\
\hline 1 & 帆有 & 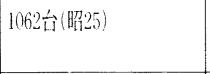 & 太平洋戦争中心は渵州東洋帆布工場建設 & $\begin{array}{l}\text { 東洋㕨布廃業後、その下請工場が } \\
\text { 衣料用厚地織物に転換 }\end{array}$ \\
\hline & 包带・ガーゼ & $\begin{array}{l}900 \text { 台、年敵200億门 } \\
\text { (半11) }\end{array}$ & $\begin{array}{l}\text { 小小幅織機下請貸与?晒、殺菌、製品化 } \\
\text { 一貫生産 3販売網確立、寡占支配 }\end{array}$ & $\begin{array}{l}\text { 平成 } 8 \text { 年: 川本包带材料、川本商事、 } \\
\text { 川本医専商事 } 3 \text { 社方合併して川本 } \\
\text { 産業となる }\end{array}$ \\
\hline
\end{tabular}

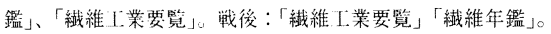
なし存続。 
経営史学 第38巻第 4 号

別表 1 「産地大

\begin{tabular}{|c|c|c|c|c|c|c|c|c|c|c|}
\hline 機業名 & 場所 & 類型 & $\begin{array}{l}\text { 戦前の } \\
\text { 规模 }\end{array}$ & \begin{tabular}{|l|}
$\begin{array}{l}\text { 戰㣪の事 } \\
\text { 業 }\end{array}$ \\
\end{tabular} & \begin{tabular}{|l|} 
廃業力存 \\
紸
\end{tabular} & 廃業時期 & 㓣業時期 & 倽業者 & 創業者出自 & 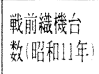 \\
\hline $\begin{array}{l}\text { 【泉南0】 } \\
\text { 带谷商沾 } \\
\text { (戦後：带谷織布) }\end{array}$ & 貝塚市 & B & 超大手 & 織布 & 廃業 & $\begin{array}{l}\text { (年) } \\
\text { 平成 } 6\end{array}$ & $\begin{array}{r}\text { (年) } \\
\text { 仲買 }(\text { 明20) } \\
\text { 工場 }(\text { 大 } 1)\end{array}$ & $\mid$\begin{tabular}{|l|} 
带谷幸助 \\
带谷吉次郎
\end{tabular} & 仲買人 & $\begin{array}{l}\text { (它) } \\
3.708\end{array}$ \\
\hline 中林綿布 & 熊取町 & B & 大手 & 織布 & 廃業 & 平成 6 & 明治 40 & 中林採次郎 & 農家 & 2.306 \\
\hline $\begin{array}{l}\text { 熊取蟣物 } \\
\text { 戦後：熊取紡績〉 }\end{array}$ & 熊取町 & B & 大手 & $\begin{array}{l}\text { 紡赬 } \\
\text { 㵶布 }\end{array}$ & 売却 & 昭和22 & 大正1 & 原文斗 & 地主 & 1.165 \\
\hline 川崎綿布 & 岸和田市 & B & 大手 & なし & 廃業 & 戦時中 & 明治40 & 川崎德太郎 & 小綿商 & 1.154 \\
\hline $\begin{array}{l}\text { 南織物 } \\
\text { (戦後：南紡績) }\end{array}$ & 貝塚市 & B & 大手 & \begin{tabular}{|l} 
絖績 \\
緎布
\end{tabular} & 廃業 & 平成 1 & 明治 23 & 南尖五郎 & 木綿商 & 1.546 \\
\hline $\begin{array}{l}\text { 㙁浴織布 } \\
\text { (現在名: シオ夕二) }\end{array}$ & \begin{tabular}{|l} 
泉佳野市 \\
工場島根県 \\
侁賀県
\end{tabular} & E & なし & 織布 & 存続 & & 昭和 30 & 增谷春雄 & 農家 & \\
\hline 中野織布 & $\begin{array}{l}\text { 貝塚市 } \\
\text { 工場本社、 } \\
\text { 九州6 个工場 }\end{array}$ & D & 中小 & $\begin{array}{l}\text { 織布 } \\
\text { 紡績 }\end{array}$ & 倒产 & 平成 7 & 大正 5 & 中野源之助 & $\begin{array}{l}\text { 南織物 } \\
\text { 江奉公 }\end{array}$ & 94 \\
\hline $\begin{array}{l}\text { 泉北司】 } \\
\text { 久保芴織布 } \\
\text { (戦後：久保物) }\end{array}$ & $\begin{array}{l}\text { 泉北郡北松 } \\
\text { 尾村内田 }\end{array}$ & B & 大手 & \begin{tabular}{|l} 
紡績 \\
織布
\end{tabular} & 溌業 & 昭和52 & 明治 31 & 久保留太郎 & 伸嘪人 & 2.050 \\
\hline $\begin{array}{l}\text { 森田織布 } \\
\text { (戦捘：森田紡績〉 }\end{array}$ & $\begin{array}{l}\text { 泉北郡国府 } \\
\text { 村府中 }\end{array}$ & B & 大手 & $\begin{array}{l}\text { 紡績 } \\
\text { 織布 }\end{array}$ & 廃業 & 昭和6? & 明治44 & 森田菊郎 & $\begin{array}{l}\text { 農業 } \\
\text { 綿险 }\end{array}$ & 1.860 \\
\hline $\begin{array}{l}\text { 大鳥織布 } \\
\text { (現在名:オオトリ) }\end{array}$ & 鳳村大鳥 & A & 大手 & 織布 & 存続 & & 大䜣 8 & 中山奈良蔵 & 木綿商 & 1.322 \\
\hline 東洋帆布 & 春木町 & D & 中小 & 織布 & 廃業 & 昭和 32 & 大正. 7 & 大阪斯界人 & & 200 \\
\hline $\begin{array}{l}\text { 川本包带 } \\
\text { (現在名: 川本産業) }\end{array}$ & $\begin{array}{l}\text { 泉北郡忠岡 } \\
\text { 町 }\end{array}$ & C & 中小 & $\begin{array}{l}\text { 包带. } \\
\text { ガーゼ一 } \\
\text { 貫生産、 } \\
\text { 製造卸 }\end{array}$ & 存続 & & 大正 3 & 1111 本新之助 & $\begin{array}{l}\text { 棉問屋 } \\
\text { 泉谷墑店 } \\
\text { 次奉公 }\end{array}$ & \\
\hline
\end{tabular}

出所）戦前：阿部武司著「日本における産地綿織物業の展開」第4章「産地大経営」表4-1, 丧4-6及び「紡織年

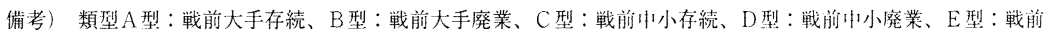


経営」の事例

\begin{tabular}{|c|c|c|c|c|}
\hline $\begin{array}{l}\text { 戦前工 } \\
\text { 場数 }\end{array}$ & 戦前品種 & 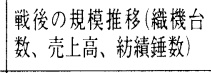 & 特色,廃業理由、存続理由等 & 備考 \\
\hline 3 & 緗布. 天然 & $\begin{array}{l}240(\text { 昭 } 35) \rightarrow 300 \text { 台 }(\text { 昭 } 54) \\
\rightarrow 200(\text { 昭60) } \rightarrow 123(\text { 平 } 5)\end{array}$ & $\begin{array}{l}\text { 戦前: 加藤六郎右衛門、杉浦憲弋コンビ経営 } \\
\text { 戦後：信友(名古屋䄉維商社) } 50 \% \text { 資本参加 } \\
\text { により信友主導の経営(信友主体の賃織) }\end{array}$ & $\begin{array}{l}\text { 平成 } 1 / 2 \text { 年のマンション分謢で成功 } \\
\text { 中七廃業後、その商権は岡德に継承 } \\
\text { される } \\
\end{array}$ \\
\hline \multirow[t]{5}{*}{6} & $\begin{array}{l}\text { 天垈·綾. } \\
\text { 細布・粗布 } \\
\cdot \text { 金巾 }\end{array}$ & $\begin{array}{l}2221(\text { 昭 } 35) \rightarrow 2479(\text { 昭 } 45) \\
\rightarrow 1218(\text { 昭 } 60) \rightarrow 540 \\
(\text { 平 } 2) \rightarrow 120 \text { 台 }(\text { 平 } 12)\end{array}$ & 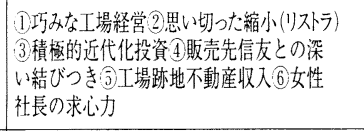 & 安藤社長の夫、嘉治氏は知多市長 \\
\hline & & $\begin{array}{l}\text { 450台(佁幅)727台 } \\
\text { (小幅) } 59000 \text { sp (平12) }\end{array}$ & ヤオ八ン破綻による不動産收入の途䋓え & 昭和26年紡繢部門を山田紡績とする \\
\hline & $\begin{array}{l}\text { ダマスク } \\
\text { テーブルクロ } \\
\text { ス }\end{array}$ & $\begin{array}{l}\text { 染色·織・カレンダー仕上 } \\
\text { 一貫.T場、年商130億円 } \\
\text { (平11) }\end{array}$ & 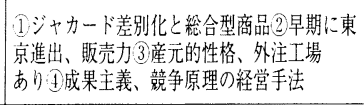 & \\
\hline & $\begin{array}{l}\text { タママスク } \\
\text { テーブルクロ } \\
\text { ス }\end{array}$ & & $\begin{array}{l}\text { 1)円高によるダマスクテーブルクロスの輸出 } \\
\text { 難 } \\
\text { 2東洋紡との合亣で紡續経営(播州紡績) }\end{array}$ & $\begin{array}{l}\text { (1)織布業廃業、産元業に集中 } \\
\text { 2工場跡地ダイーに貨貸 }\end{array}$ \\
\hline & & $\begin{array}{l}\text { 革新䋖機480台、年商 } \\
80 \text { 䪰川(平 } 5 \text { ) }\end{array}$ & 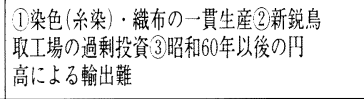 & \\
\hline 8 & $\begin{array}{l}\text { 天等·金巾· } \\
\text { 細布·綗 }\end{array}$ & $\begin{array}{l}2682, \text { タオル82(昭35) } \rightarrow \\
1429, \text { タオル98 }(\text { 昭48) } \rightarrow \\
436 \text { 台、タオル108台(昭55) }\end{array}$ & 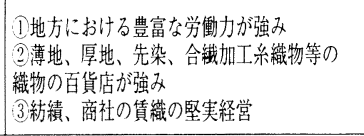 & $\begin{array}{l}\text { 本社工場跡地仙老人保徤施設と養老 } \\
\text { 老人ホームで地域社会に貢献 }\end{array}$ \\
\hline \multirow[t]{4}{*}{2} & $\begin{array}{l}\text { 綿蟣物 } \\
\text { 人絹柾物 }\end{array}$ & 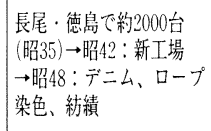 & 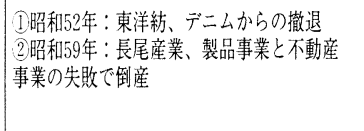 & 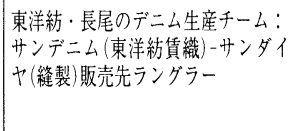 \\
\hline & 備捘絣 & $\begin{array}{l}\text { 年商105億円(平11) } \\
\text { 344台スルザー(昭63) }\end{array}$ & $\begin{array}{l}\text { 1デニム差別化商品2織・ロープ染色・紡績 } \\
\text { 一貫生産了独自の販売(ユニクロとの取組) }\end{array}$ & 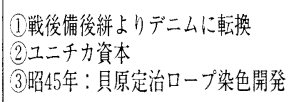 \\
\hline & 小倉服地 & $\begin{array}{l}\text { (昭46)織布1 } 1.053 \text { 台 } \\
(\text { 昭62) 年商73億円 }\end{array}$ & $\begin{array}{l}\text { 厚地、ワーキング、カジュアル用生地 } \\
\text { 糡布、染色(後染)一貫加工 }\end{array}$ & \\
\hline & & 年商148億円(昭51) & $\begin{array}{l}\text { 昭和24年興国人絹(與人)と二喜の合弁会社 } \\
\text { として発足 } \\
\text { 昭和52年與人会社更生法 }\end{array}$ & $\begin{array}{l}\text { (熊本工場はコーボテキスタイルと } \\
\text { して存続 } \\
\text { (2昭和53年：紛績の豊川工場を分離 } \\
\text { 䗑立して豊川テキスタイルとなる }\end{array}$ \\
\hline
\end{tabular}


経営史学 第 38 巻第 4 号

別表 2 産地大

\begin{tabular}{|c|c|c|c|c|c|c|c|c|c|c|}
\hline 機業名 & 場所 & 類型 & $\begin{array}{l}\text { 戦前の } \\
\text { 规模 }\end{array}$ & $\begin{array}{l}\text { 戰後の事 } \\
\text { 業 }\end{array}$ & \begin{tabular}{|l} 
廃業办存 \\
続
\end{tabular} & 廃業時期 & 創業時期 & 創業者 & 創業者出自 & $\begin{array}{l}\text { 戰前織機台 } \\
\text { 数 (昭11) }\end{array}$ \\
\hline $\begin{array}{l}\text { 【知多(3】 } \\
\text { 中七木綿 } \\
\text { (戦後：中七綿布) }\end{array}$ & 知多市岡田町 & B & 大手 & 織布 & 㪄業 & $\begin{array}{l}\text { 年) } \\
\text { 平成 } 7\end{array}$ & 明治29 & $\begin{array}{l}\text { 加藤少郎 } \\
\text { 右衛門 }\end{array}$ & $\begin{array}{l}\text { 木綿問司 } \\
\text { 中島七在 } \\
\text { 幥門奉公 }\end{array}$ & 1.624 \\
\hline $\begin{array}{l}\text { 岡德 } \\
\text { (現在名: オカトク) }\end{array}$ & 知多市岡田町 & A & 大手 & 織布 & 存続 & & 大正 2 & 安藤梅吉 & $\begin{array}{l}\text { 中七棉 } \\
\text { 俸公 }\end{array}$ & $\begin{array}{l}2.286 \\
\text { (広幅) }\end{array}$ \\
\hline $\begin{array}{l}\text { 山田紡績 } \\
\text { (戰前：山田商店) }\end{array}$ & $\begin{array}{l}\text { 半田市乙川 } \\
\text { 吉野町 }\end{array}$ & B & 大手 & $\begin{array}{l}\text { 紡績 } \\
\text { 纖布 }\end{array}$ & 倒產 & 平成12 & 大正 4 & 山田佐- & 木綿商 & $\begin{array}{l}292 \text { (広幅) } \\
984 \text { (小幅) }\end{array}$ \\
\hline 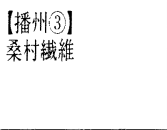 & 多可郡中町 & C & 中小 & $\begin{array}{l}\text { 織布 } \\
\text { 簿 } \\
\text { かレンダー }\end{array}$ & 存続 & & 昭和 3 & 桑村龍太郎 & 地方官吏 & $\begin{array}{r}\ddot{シ ゙ ャ カ ー ト ~} \\
50\end{array}$ \\
\hline 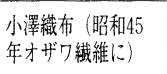 & 西脇甫 & D & 中小 & \begin{tabular}{|l} 
織布 \\
系染
\end{tabular} & 廃業 & 昭和51 & 昭和 8 & 小澤通秀 & & ジャカート \\
\hline $\begin{array}{l}\text { 德岡商店 } \\
\text { (平成 } 5 \text { 年卜和加) }\end{array}$ & $\begin{array}{l}\text { 西脇市 } \\
\text { 工場島根 }\end{array}$ & D & 中小 & $\begin{array}{l}\text { 織布 } \\
\text { 糸染 }\end{array}$ & 倒産 & 平成 9 & 昭和13 & 德岡武治 & & \\
\hline $\begin{array}{l}\text { 【四国2】 } \\
\text { 酒六 }\end{array}$ & $\begin{array}{l}\text { 愛媛県 } \\
\text { 八幡浜 }\end{array}$ & B & 大手 & \begin{tabular}{|l} 
縕布 \\
犺 \\
製系
\end{tabular} & 溌業 & $\begin{array}{l}\text { 平3:織布 } \\
\text { 平11: } \\
\text { 㚈 }\end{array}$ & $\begin{array}{l}\text { 明治21 } \\
\text { 昭和 6: } \\
\text { 丸喜綿布 }\end{array}$ & 酒井六十郎 & $\begin{array}{l}\text { 譏屋の } \\
\text { 見習 } \mathrm{I}\end{array}$ & 1.600 \\
\hline $\begin{array}{l}\text { 長尾産業·徳島 } \\
\text { 綿業 (昭和43年 } \\
\text { 長尾テキス夕夕ルに) }\end{array}$ & 德島市上鮎喰 & B & 大手 & $\begin{array}{l}\text { 織布 } \\
\text { 口-フ染色 } \\
\text { 紡績 }\end{array}$ & $\begin{array}{l}\text { 売却 } \\
\text { (日清紡) }\end{array}$ & 昭和60 & 明治 41 & 長尾傳蔵 & 行商人 & 2.356 \\
\hline $\begin{array}{l}\text { (中国讧) } \\
\text { 貝原織布 } \\
\text { (現在名：カイハラ) }\end{array}$ & $\begin{array}{l}\text { 広島県芦品 } \\
\text { 郡新市町 }\end{array}$ & C & 中小 & $\begin{array}{l}\text { 織布 } \\
\square-f \text { 染色 } \\
\text { 紡績 }\end{array}$ & 存続 & & 明治 26 & 貝原助治郎 & & 250 \\
\hline 正織興業 & $\begin{array}{l}\text { 岡山県倉敷 } \\
\text { 市茶屋町 }\end{array}$ & C & 中小 & $\begin{array}{l}\text { 織布 } \\
\text { 後染 } \\
\text { (紡績) }\end{array}$ & 存続 & & 明治13 & 姫井嘉吉 & 木綿商 & 1.300 \\
\hline $\begin{array}{l}\text { に三河门1 } \\
\text { 與国紡織 }\end{array}$ & $\begin{array}{l}\text { 蒲郡市 } \\
\text { 工場：蒲郡、 } \\
\text { 熊本、豊川 }\end{array}$ & D & $\begin{array}{l}\text { 中小 } \\
\text { (二喜) }\end{array}$ & $\begin{array}{l}\text { 織布 } \\
\text { 紡績 } \\
\text { 維製 }\end{array}$ & $\begin{array}{l}\text { 廃業 } \\
\text { (和議) }\end{array}$ & & $\begin{array}{l}\text { 明治38 } \\
\text { (一喜) }\end{array}$ & 二村喜助 & & \\
\hline
\end{tabular}




\begin{tabular}{|c|c|c|c|c|c|}
\hline 知 & & & & & 也 \\
\hline $\begin{array}{ll}\text { 中 } & \text { 岡 } \\
\text { 七 } & \text { 德 } \\
\text { 木 } & \\
\text { 綿 } & \end{array}$ & $\begin{array}{l}\text { 川 } \\
\text { 本 } \\
\text { 包 } \\
\text { 带 }\end{array}$ & $\begin{array}{l}\text { 大 } \\
\text { 舃烏 } \\
\text { 長 緎 } \\
\text { 港 維 } \\
\text { I: } \\
\text { 埸 }\end{array}$ & & 资 & $\begin{array}{l}\text { 訪 } \\
\text { 問 } \\
\text { 機 } \\
\text { 業 } \\
\text { 名 }\end{array}$ \\
\hline $\begin{array}{cc}\ddot{0} & \ddot{0} \\
0 & 0 \\
\ddot{y} & 9 \\
\dot{0} & 0\end{array}$ & $\begin{array}{l}\overrightarrow{\overrightarrow{0}} \\
\stackrel{0}{\dot{y}} \\
\vec{y}\end{array}$ & 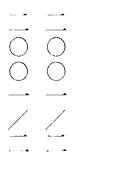 & $\begin{array}{l}\ddot{\vec{O}} \\
\underline{O} \\
\underline{2}\end{array}$ & $\begin{array}{l}0 \\
0 \\
\end{array}$ & $\begin{array}{l}\text { 訪 } \\
\text { 問 } \\
\text { 年 } \\
\text { 月 }\end{array}$ \\
\hline 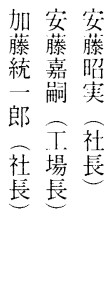 & 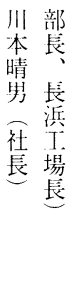 & 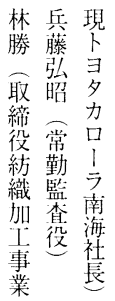 & $\begin{array}{l}\text { 久 } \\
\text { 保 } \\
\text { 憬 } \\
\text { 廃 } \\
\text { 業 } \\
\text { 時 } \\
\text { 取 } \\
\text { 締 }\end{array}$ & $\begin{array}{l}\text { 人 } \\
\text { 保 } \\
\text { 宗 } \\
\text { 登 } \\
\text { 業 } \\
\text { 特 } \\
\text { 由 }\end{array}$ & $\begin{array}{l}\text { 面 } \\
\text { 会 } \\
\text { 者 } \\
\text { 訪 } \\
\text { 問 } \\
\text { 時 } \\
\text { 役 } \\
\text { 職 } \\
\text { 名 }\end{array}$ \\
\hline
\end{tabular}

约は元経てけでけ $\overbrace{}^{\widehat{3}}$ 遠三南

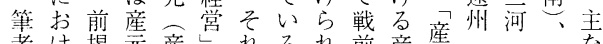
者け揭完産机る机前産産地泉な がるっが地はに。たに地圤浜愛泉短

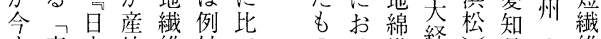
ま産本地維外令のけ織経、県泉維 で地にの問的てでる物営高蒲泉織 に大扮中屋な播あ大業と島郡北物 訪経け核存州 問棠る体は在 し旁と存で備 た老地し在あ後 一指綿てし 六す織存なた岡 社。物在少。 の 業しつそ リのてた机四 ス展いのは国 卜開たに白 は違对生三 次第心L地河 の四にて産の 通章毛上地産 节早記は地 早よ記は地 本る産戦は 綿。地前 織戦方地 業後産大

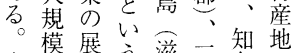
本機開名㖙責聟地 稿業多賀州多、織

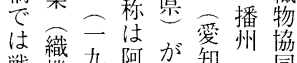
戦機九阿が知同 前機八部京県西絹 秐九武る西脇合 戦数年、司尾哭

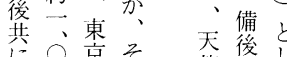

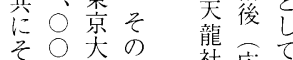
そ学著社広て

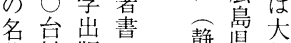
称以版鎎県阪 老上会沓岡県岡辣 襲にのに付中打山泉

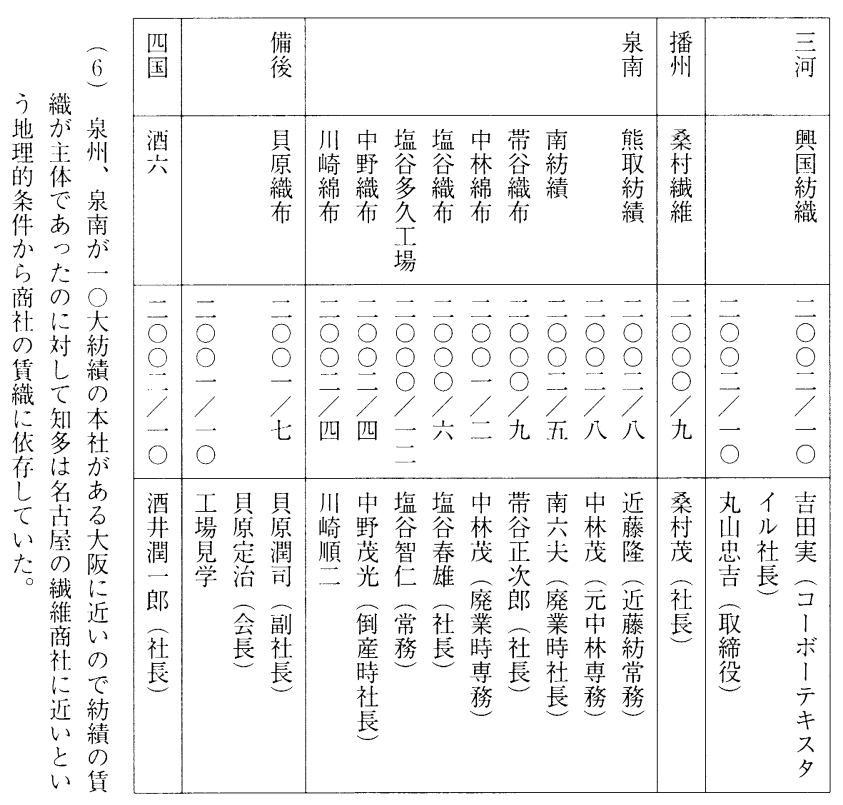


経営史学 第 38 巻第 4 号

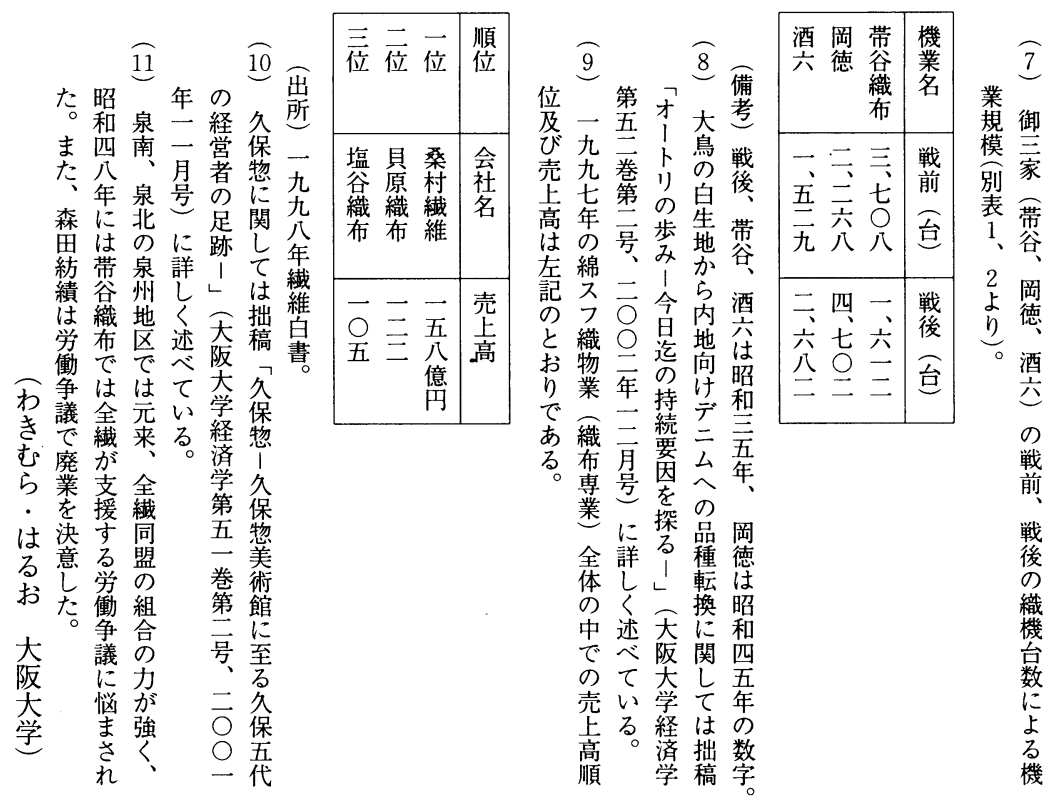

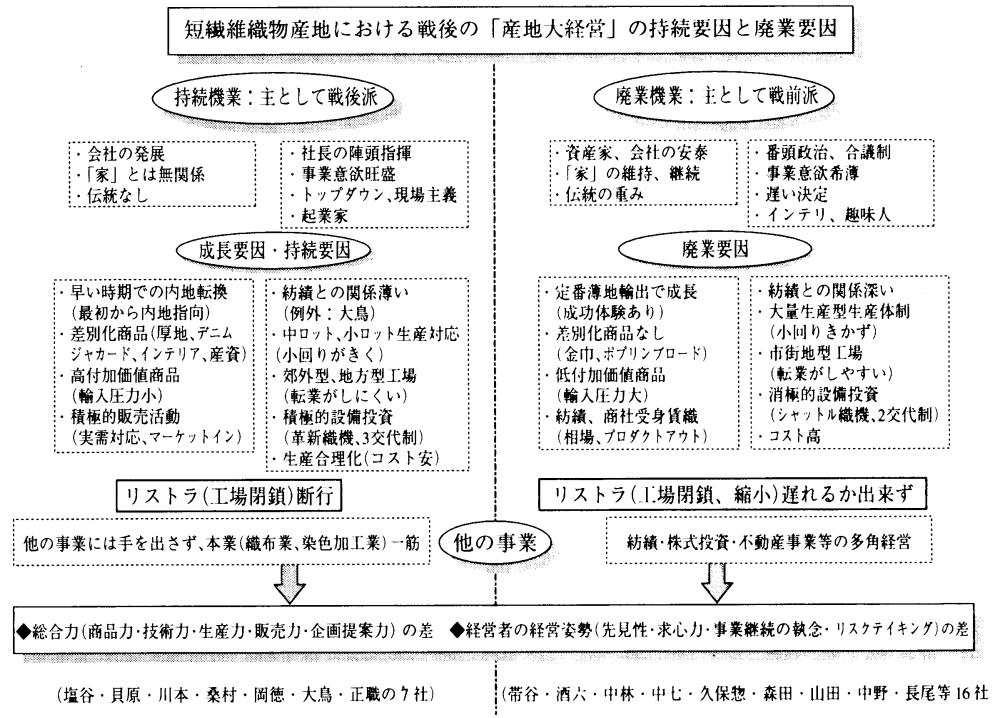




\title{
THE DEVELOPMENT AND DECLINE OF LARGE INDEPENDENT COTTON TEXTILE WEAVERS AFTER THE SECOND WORLD WAR
}

\author{
Haruo Wakimura \\ University of Osaka
}

Large independent cotton textile weavers used to be located in the cotton weaving textile industrial areas in the western part of Japan. The purpose of this paper is to analyze the various factors contributing to the successes or failures of large cotton weavers; while some large cotton weavers succeeded and survive to this day, many more were forced to discontinue their business activities. The methods of analysis are based on case studies of each company through interviews, or oral history.

The definition of "large" cotton weaver in this paper is 1) ownership of 1,000 rooms, either before or after the Second World War or 2) a turnover that had once exceeded 8 billion yen.

Out of 23 cotton weavers that fall under these conditions, 7 companies still survive, while 16 have disbanded.

Concerning the origins of various cotton weaving industrial areas located in Sennan, Senboku, Chita, Banshu, Enshu, Chugoku, etc., 15 companies out of 23 were situated in Sennan, Senboku, and Chita. Most of the large weavers were originally form these three areas because of contracts from large textile mills and trading firms for mass production of grey fabrics for export.

From the middle-1980s, however, export of such mass production fabrics as poplin, broad and lawn for started to wane because of yen appreciation production of these fabrics consequently lost in the competition for exports, and a big increase in imported fabrics and apparels followed.

Those large weavers who succeeded in converting to either heavy gauge fabrics, like twill or denim, or high value-added thin gauge fabrics for domestic usage, which China could not produce, were able to survive. Those who relied on large textile mills for mass production products for export failed to survive.

Finally, this paper concludes that the main factor determining the ability or failure to survive, was the speed at which company management was capable of switching its products from the exports to domestic market. 